\title{
A industrialização no Rio Grande do Sul nas primeiras décadas da República: a organização da produção e as condições de trabalho (1889-1920)
}

Evangelia Aravanis

Resumo: Este artigo visa contribuir para o estudo das condições de trabalho e da organização da produção fabril existentes no Rio Grande do Sul nas primeiras décadas da República (1889 a 1920). Especificamente, busca evidenciar as causas de acidentes de trabalho, as condições de higiene existentes, o poder aquisitivo dos salários dos operários e a divisão sexual do trabalho em vigor nas fábricas, bem como averiguar como todos esses elementos repercutiram sobre o corpo do operário.

Palavras-chaves: Rio Grande do Sul na 1a. República; condições de trabalho fabris; divisão sexual do trabalho.

Abstract: The article aims to contribute to the study of work conditions and the Organization of the existing production plant in Rio Grande do Sul in the first decades of the Republic (1889-1920). Specifically, search highlighting causes of accidents at work, the existing conditions of hygiene, the purchasing power of wages of workers and the sexual division of labour in force in the factories. Search digs how all these factors had an impact on the body of the worker.

Keywords: Rio Grande do Sul in 1‥ Republic; industrial working conditions; sexual division of labor.

Neste artigo tenho por objetivo contribuir para o estudo das condições de trabalho e da organização da produção fabril existente no Rio Grande do Sul nas primeiras décadas da República, mais precisamente nos anos de 1889 a 1920. Esta temática, ainda que explorada pela historiografia local, apresenta elementos que não foram analisados mais detalhadamente. Assim, o artigo busca avançar nesta discussão, visando suprimir algumas destas lacunas historiográficas. No caso aqui específico, busco evidenciar fatores que levaram a acidentes de trabalho, as condições de higiene fabril existentes, o poder aquisitivo dos salários dos operários e a divisão sexual do trabalho em vigor nas fábricas. Busco

* Professora da ULBA. Doutora em História pela UFRGS.

Revista Mundos do Trabalho, vol. 2, n. 3, janeiro-julho de 2010, p. 148--180. 
também averiguar como todos esses elementos repercutiram sobre a corporeidade operária.

A historiografia local tratou das questões apontadas de forma esparsa e residual, via de regra quando os autores se propunham a realizar um panorama dos primórdios da industrialização no estado. Esta bibliografia, gerada em grande parte nos anos 70 e 80, trouxe muitos dados sobre a realidade de trabalho dos operários, contudo, exatamente por se propor a realizar mais um panorama ou empreender estudos específicos de unidades fabris, os dados levantados acabaram não sendo detidamente estudados ${ }^{1}$. A minha proposta aqui, como se observa, é a de avançar um pouco nesta discussão.

As fontes documentais que pesquisei para realizar a pesquisa foram diversificadas. Esta documentação constituiu-se de veículos da imprensa operária do estado ${ }^{2}$, de jornais não operários pelos quais a militância periodicamente se pronunciava na capital $^{3}$, de dois jornais diários importantes do Rio Grande do Sul ${ }^{4}$ e de documentos oficiais do Governo do Estado. Todos esses documentos acabaram por definir o presente recorte cronológico do trabalho, já que eles numericamente se concentram nos anos de 1889-1920.

A industrialização do Rio Grande do Sul, na virada do século XIX para o século XX, situa-se em dois pólos produtores principais, com feições bastante distintas entre si. Um é formado pelos estabelecimentos situados em Rio Grande e Pelotas, e o outro é composto

\footnotetext{
${ }^{1}$ Dentre esta bibliografia, cito: LONER, B. Construção de classe: operários de Pelotas e Rio Grande (1888-1937). Pelotas, Universidade Federal de Pelotas: Ed. Universitária, Unitrabalho, 2001; PETERSEN, S. El proletariado urbano urbano en Rio Grande do Sul, 1888-1919. México: U.N.A.M., 1977; __ As greves no Rio Grande do Sul na República Velha. In: DACANAL, J. I. e GONZAGA, S. (org.). RS: Economia e Política. Porto Alegre: Mercado Aberto, 1993; __. 'Que a união operária seja nossa pátria': história das lutas dos operários gaúchos para construir suas organizações". Santa Maria: editoraufsm; Porto Alegre: Ed. da Universidade/UFRGS, 2001; PESAVENTO, S. A burguesia gaúcha: dominação do capital e disciplina do trabalho (RS 1889-1930). Porto Alegre: Mercado Aberto, 1988; REICHEL, H. A industrialização no Rio Grande do Sul na República Velha. In: DACANAL, GONZAGA (org.) RS: Economia e Política. Porto Alegre: Mercado Aberto, 1993; SILVA, M. G. Mulheres operárias em Pelotas e Rio Grande (1890-1920). Porto Alegre: IFCH/PUCRS, 1998; SILVA, L. H. Mulher e Trabalho: Estrutura ocupacional feminina no RS (1920-1970). Porto Alegre: IFCH/UFRGS, Porto Alegre, 1977; VASCONCELLOS \& MARCON. O trabalho feminino na indústria têxtil em Porto Alegre 1900-1920. Revista Textura. v.3. Canoas: 2000.

2 Jornais operários: A Luta (1906-1911); A Democracia (1905-1907); Avante (1901-1902;1908); O Alfaiate (1907); L'avvenire (1892, 1893); O Edifício Social (1903); O Operário (1889); O Proletário (1896), A Voz do Operário (1889); A Vanguarda (1914); La Scintilla (1896); Democracia Social (1893); A Luta (1916); O Operário (1892): De Rio Grande Echo Operário (1897-1899; 1901); Artista (1891; 1903-1904); O Proletário (1906); A Razão (1896), Intrépido (1910); O Operário (1902) - Cruz Alta; A Bigorna (1917) - Encruzilhada; A Evolução (1908) - Bagé.

${ }^{3}$ A Gazetinha (1891-1899); O Diário (1911-1915); Echo do Povo (1908-1913); Petit Journal (1905-1906) e Correio do Povo (1896-1900; 1911-1917).

${ }^{4}$ Correio do Povo (1896-1900; 1911-1917) e A Federação (1890-1900; 1907-1917). 
pelas unidades localizadas em Porto Alegre, Caxias do Sul e Vale do Rio dos Sinos ${ }^{5}$. Uma breve análise de cada um destes pólos, a fim de dar substrato à análise que segue, se faz aqui necessária.

O primeiro pólo mencionado, apesar da proximidade geográfica das unidades que o compunham, não era constituído de unidades industriais homogêneas. Em Rio Grande o modelo hegemônico de indústria existente se caracterizava pela presença de grandes estabelecimentos industriais, com significativo capital investido e até com a participação de capital estrangeiro (como a Cia. União Fabril, Ítalo-Brasileira e Leal Santos). Caracterizava-se, também, por índices de emprego de mão de obra e de nível de qualificação tecnológica elevada, bem como pela pouca diversificação de ramos industriais, fato decorrente de esta industrialização se voltar para o mercado nacional através de poucos produtos e em que sua competitividade já estava estabelecida: a tecelagem, a indústria de fumos (charutos) e alimentícia (compotas e enlatados) ${ }^{6}$. Destaco, em especial, a indústria têxtil desta região, que era altamente qualificada no aspecto tecnológico e que já empregava de forma expressiva a mão de obra feminina e infantil e, dentre estas, a Companhia União Fabril, fundada por Carlos Guilherme Rheingantz, em 1873. Esta companhia têxtil, que instalou a primeira fábrica do estado em 1874, contava com três unidades fabris (lanifício, cotonifício e aniagem), num total de 900 operários, além de 100 costureiras que trabalhavam em domicílio. Boa parte de sua produção se voltava para o mercado nacional, e dois terços dela eram enviados para o Rio de Janeiro ${ }^{7}$. Já o que se pode chamar de "modelo" industrial minoritário existente em Rio Grande tinha feições um tanto opostas a esse, ou seja, comportava estabelecimentos de pequeno porte e com uma produção de cunho artesanal, constituída por artigos voltados para o abastecimento do mercado local: doces, compotas, calçados, massas etc. ${ }^{8}$

No caso da região de Pelotas, a segunda localidade que compunha este primeiro pólo, o que se verificava era uma estrutura de industrialização um pouco mais equilibrada no que se refere à quantificação existente entre indústrias de grande porte e tecnologia avançada e pequenas unidades de caráter artesanal, ainda que com vantagem para as

\footnotetext{
${ }^{5}$ SINGER. Desenvolvimento e Crise. São Paulo: Difusão Européia, 1968, p. 171-177; REICHEL. Op.cit, p. $255-262$.

${ }^{6}$ LONER, B., op.cit. p. 44-50.

${ }^{7}$ SINGER, P., op.cit., p. 171-172.

${ }^{8}$ SILVA, Ma. Amélia G. da. Mulheres operárias em Pelotas e Rio Grande (1890-1920). Porto Alegre: IFCH/PUCRS. Dissertação de Mestrado, 1998. Reprodução Xerográfica, 1998, pp. 31-35.
} 
primeiras. Observo, contudo, que tal como os grandes estabelecimentos de Rio Grande, estas unidades produtivas maiores de Pelotas trabalhavam voltadas para o mercado nacional, em grande parte, beneficiando os produtos derivados de uma outra importante atividade produtiva da região, a pecuária. Destaco dentre estas as fábricas de calçados. Já as unidades de pequeno porte desta localidade tinham como alvo o mercado regional e, assim sendo, acabavam por produzir os mais diferentes tipos de produtos, a partir de matériasprimas muito variadas: compotas, licores, charutos etc. Havia então, convivendo nesta localidade, tanto um expressivo número de indústrias transitando para um modelo de grande porte e tecnologia avançada para a época, que beneficiavam produtos derivados da pecuária, visando ao mercado nacional, como vários estabelecimentos de pequeno porte, com feições artesanais, que produziam direcionados para o mercado regional ${ }^{9}$.

Já o segundo pólo industrial do estado - composto por Porto Alegre, Caxias do Sul e Vale do Rio dos Sinos - apresentava, além de uma certa similitude com Pelotas, no caso este acento no caráter artesanal de bom número de suas unidades, um núcleo mais numeroso de estabelecimentos, embora menores, e com maior diversificação industrial, fato decorrente de estas indústrias buscarem primeiramente atender às múltiplas necessidades de consumo da população da zona colonial. É somente após ter consolidado a sua posição no mercado consumidor regional que este pólo industrial se lança em busca do mercado nacional ${ }^{10}$.

No documento "Dados estatísticos sobre o município de Porto Alegre", organizado pelo escriturário Olympio A. Lima no ano de $1912^{11}$, a caracterização de unidades de cunho artesanal para a Capital e de sua diversificação nos ramos de produção fica bem evidente. Neste documento, quase se equiparam o número de oficinas (149) com os de fábricas (154). Como oficinas são citadas, por exemplo, as de cartonagem, fundição, carpinteiro, ferreiro e litógrafo. Já como fábricas, as de fumo, banha, biscoitos, colchas, cervejas, calçados, sabonetes, vidros, dentre outras.

Considerando esta breve explanação das características da industrialização que se implantava no estado nas primeiras décadas da República, conclui-se que havia localmente a coexistência de dois "tipos" básicos de espaços de produção, bem como,

\footnotetext{
${ }^{9}$ LONER, B., op.cit., p. 44-54 e SILVA, M.A., p.31-35.

${ }^{10}$ REICHEL. Op.cit,, p. 262; SINGER, op.cit., P. 1968, p. 171-172.

${ }^{11}$ Dados Estatísticos sobre o município de Porto Alegre. Olympio de Azevedo Lima (org.). Porto Alegre: Livraria do Comércio, 1912.
} 
consequentemente, de dois "tipos" de operários fabris, os artesãos "das oficinas" e os operários "das fábricas". É relevante nesta perspectiva também mencionar que, em alguns casos, conjugavam-se, em um mesmo espaço, o trabalho de cunho artesanal e o trabalho fabril. A partir de dados obtidos na documentação ${ }^{12}$ observei que, mesmo aquelas unidades produtivas com significativo nível tecnológico para a época, como a Leal, Santos \& Cia. (de Rio Grande), H. Ritter \& Filhos e Neugebauer Irmãos (de Porto Alegre), vinham fazendo uso de oficinas, já que junto a estas funcionavam marcenarias, serralherias, funilarias ${ }^{13}$, litografias, tipografias etc. Elas eram as responsáveis, na maior parte das vezes, por confeccionar os invólucros e caixas de armazenagem dos produtos fabricados. Observo ainda, nesta linha, que o operário "envergador" da fábrica de móveis de Walter Gerdau claramente conjugava sua atividade de feição artesanal com o maquinário, ou seja, realizava um trabalho de cunho artesanal diretamente vinculado a uma produção altamente mecanizada $^{14}$.

Ressalto que esta breve apresentação aqui feita fornece, em seu esquematismo, um quadro um tanto estático da industrialização gaúcha que esconde, por sua vez, as dinâmicas internas que acompanham o processo de desenvolvimento da indústria regional. É preciso reconhecer que nesse processo havia, ainda que com situações de estagnação - pequenas e grandes indústrias vivendo prolongados processos de paralisação -, um rumo que se delineava, principalmente a partir do início do século XX, e que era o da instituição do sistema de fábrica. Ou seja, as oficinas, paulatinamente, vinham sendo substituídas ou numericamente superadas pelas fábricas.

Nos estabelecimentos industriais de pequeno porte, as oficinas, como se pode deduzir considerando o caráter artesanal mencionado de sua produção, o capital não havia ainda implementado uma significativa divisão técnica do trabalho. Lá, por não existirem máquinas, ou por serem estas muito simples e/ou poucas, o operário ainda detinha o conhecimento de todo - ou quase todo - o processo produtivo, o que também significa que

\footnotetext{
${ }^{12}$ Relatório apresentado ao Ex. Sr. Dr. Protásio Alves / Secretaria do estado dos Negócios do Interior e Exterior pelo Diretor Interino Nathaniel Cunha (1916). S.n.t. ; O Rio Grande do Sul industrial. Porto Alegre: Echenique, 1907; Os Estados Unidos do Brasil: sua história, seu povo, commércio, indústria e recursos. Londres, Buenos Aires, RJ e São Paulo: The South American Intelligence Co., 1919.

${ }^{13}$ Conforme, também, anúncio no jornal operário A Democracia (Porto Alegre, 28/2/1907, p. 4) sobre a Fábrica de Doces Neugebauer.

${ }^{14}$ Relatório da Sub-Intendência do $40^{\circ}$ Distrito, apresentado ao Intendente José Montaury de Aguiar Leitão em 1918. S.n.t.
} 
o seu corpo conservava o domínio de técnicas ${ }^{15}$ que compreendiam boa parte deste processo. Aponto, igualmente, que devido a esta ausência de maquinários, o operário era ainda bastante "livre" no âmbito da produção, pois o seu ritmo de trabalho ainda provinha do ritmo laboral "natural" de seu corpo e não daquele imposto pela máquina criada pelo capitalista para melhor dominar e controlar o operário ${ }^{16}$. Uma das poucas "pressões" que se pode apontar como atuando nestes estabelecimentos, quando não a única, era aquela proveniente da disciplina ali imposta pelo patrão ou por alguns raros indivíduos com cargos de chefia, tendo em vista a qualidade da produção e a noção que o patrão começava a possuir de "tempo útil", isto é, de que todo o tempo de trabalho do operário (sua jornada laboral) deve ser transformado em mercadorias ${ }^{17}$.

Nos estabelecimentos de grande porte, as fábricas, a realidade já era bem diferente, o que não é algo inusitado, tendo em vista serem estas um fruto mais elaborado da intenção e ação do capitalista para obter maior domínio sobre a produção (da matéria-prima, da quantidade e qualidade da mercadoria produzida etc.) e o controle do operariado ${ }^{18}$.

Uma destas formas de controle se dava através da adoção, no espaço fabril, de uma fiscalização do tipo "panoptismo benthanminiano" ${ }^{19}$, situação em que um pequeno grupo de indivíduos, os mestres e contramestres - os "olheiros" do capital - tinham a tarefa de vigiar e de eliminar, fazendo uso de regulamentos punitivos e das máquinas, possíveis porosidades na produção, disciplinando e tornando, assim, o tempo (ao punir a ociosidade) e o corpo do operário (ao suprimir gestos e comportamentos supérfluos) mais produtivos para o patrão ${ }^{20}$. Em Pelotas e Rio Grande este processo de disciplinarização fabril é claramente visível na Cia. União Fabril (Rheingantz), no estabelecimento do Srs. Júlio Silva \& C., e na fábrica de tecidos

\footnotetext{
${ }^{15}$ Entende-se 'técnica' como toda a ação humana levada a cabo a partir da inter-relação de elementos como matéria, gestos, energia, objetos e conhecimentos. Ver: LEMONNIER, P. The study of Material Culture Today: Toward an Anthropology of Technical Systems. Journal of Anthropological Archaeology, n. 5, 1986, pp.4-6.

${ }^{16}$ Esta assertiva e a do parágrafo anterior são feitas com base nas análises de Fábio Erbet e Michelle Perrot. PERROT. Op.cit, p.24 e ERBER, Fábio S. A importância do estudo e do processo de trabalho: uma introdução. In: TRONTI, Mário et al. Processo de trabalho e estratégia de classe. Rio de Janeiro: Zahar, 1982, p. iii.

${ }^{17}$ THOMPSON, E. P. Tradición, revuelta y conciencia de clase: estudios sobre la crisis de la sociedad preindustrial. Barcelona: Editorial Crítica, 1984, pp. 239-295

${ }^{18}$ FOUCAULT, Michael. Vigiar e punir: nascimento da prisão. Petrópolis, RJ: 1999, pp.117-192; THOMPSON, E. P. A formação da classe operária inglesa. A árvore da liberdade. Rio de Janeiro: Paz e Terra, 1987, v.1.; PERROT, Michelle. Os excluídos da história: operários, mulheres e prisioneiros. Rio de Janeiro: Paz e Terra,1992, pp. 1749; 53-80, entre outros.

19 PERROT, M. 1992, op. cit. p.56; FOUCAULT, M., op.cit., pp. 162-187.

${ }^{20}$ THOMPSON, E. op.cit., p. 239-295. Ver também FOUCAULT, M. 1999, op. cit., p. 162-192. e PERROT, M., op.cit., pp. $66-71$.
} 
Ítalo-Brazileira ${ }^{21}$. Em Porto Alegre e São Leopoldo, identifiquei, dentre outros, os seguintes estabelecimentos com este perfil: Cia. Fiação e Tecidos Porto-Alegrense, Cia. Fabril PortoAlegrense, Cervejaria Ritter \& Filhos, Casa Alberto Bins e Fábrica de Fósforos Sul Rio Grandense 22 .

Como se observa, a idéia de "tempo útil", através deste novo mecanismo de coerção, impunha-se com mais vigor no processo produtivo das indústrias no estado. Reforçando este controle, que futuramente poderia até substituir a vigilância dos contramestres, constata-se a imposição, ao operário, de sua subordinação à disciplina rítmica ditada pela máquina, mais uniforme e intensa ${ }^{23}$.

Explícito a este respeito é o que informa o livrete "O Rio Grande Industrial", em 1907, sobre a olaria Berto Cyrio, localizada no Vale dos Sinos. Segundo este livreto, lá havia sido implantado um novo forno que "ofere[cia] a vantagem de permitir que cada operário executasse diariamente a mesma quantidade de trabalho" ${ }^{24}$.

A fábrica, enfim, impunha aos operários e imprimia, aos poucos, uma mudança no corpo e na percepção do tempo de quem ali trabalhava - que deviam agora ser mais produtivos $^{25}$. Apesar de não explicitar qual a medida de interiorização pelos operários deste processo de disciplinarização fabril em implantação, é indicativo de alguns dos efeitos sobre eles o fato de serem publicados em 1907, no jornal operário A DEMOCRACIA, vários anúncios de venda de um ícone e instrumento de controle do capital: o relógio moderno. Além dos de bolso ${ }^{26}$ eram anunciados relógios despertadores ${ }^{27}$, tidos como "próprios para trabalhadores" ${ }^{28}$.

Retornando ao espaço da fábrica, observo que a mecanização característica destes locais trazia outros processos correlatos que repercutiam também no controle do operário e

\footnotetext{
${ }^{21}$ ECHO OPERÁRIO, Rio Grande: 26/9/1897, p.2; 24/9/1898, p.4; 18/7/1899, p.2. DEMOCRACIA SOCIAL, Pelotas: 19/11/1893, p.1,2; 17/12/1893, p.3.

${ }^{22}$ A LUTA, Porto Alegre: 15/11/1906, p.3; 15/12/1906, p.2; 19/7/1908, p.2; 16/1/1909, p.4; 1/7/1910, p.2. AVANTE, Porto Alegre, 24/6/1908, p.3.

${ }^{23}$ PERROT, M. op.cit., p. 24.

24 Livreto publicado em Porto Alegre, no ano de 1907, pela editora Echenique. Objetivava fazer propaganda das indústrias e produtos rio-grandenses nas exposições industriais realizadas fora do estado, conforme frontispício da publicação.

${ }^{25}$ Ver: THOMPSON, E. P., op.cit., 1984, pp. 239-295 e THOMPSON, E. P., op.cit.1987, p.71-177.

${ }^{26}$ A Democracia, Porto Alegre, 24/3/1907, p.4; 07/4/1907, p.3; 14/4/07, p.4 e 21/4/1907, p.4.

${ }^{27}$ A Democracia, Porto Alegre, 14/2/1907, p.4 e 28/2/1907, p.4.

${ }^{28}$ Conforme anúncio, a casa $A$ Meridiana havia recebido "bonito sortimento de relógios despertadores por preços baratíssimos, qualidade garantida, próprios para trabalhadores." (A DEMOCRACIA, Porto Alegre, 14/2/1907, p.4).
} 
na conformação de seu corpo. Em primeiro lugar, inaugurava a superioridade da máquina sobre o homem, sendo este último constantemente substituído ou dominado por ela. Em segundo lugar, fundava uma disjunção entre o trabalho manual e o trabalho intelectual no interior do processo produtivo, da qual surgia, além de uma massa operária que executava tarefas mais simples, um corpo de técnicos responsáveis por relegar a estes primeiros às tarefas manuais e de execução ${ }^{29}$.

No primeiro destes casos, observei, como consequência, uma recusa pelo operariado desta superioridade da máquina, o que era claramente evidenciável quando afirmavam que quem "dá movimento às máquinas são os operários"; que "elas sem os seus braços nada são"30. Já no segundo caso verifica-se a criação de um novo tipo de operário que domina saberes e técnicas mais simples, o que o leva a "adquirir" um corpo relativamente desnudo em face dos conhecimentos que o operário-artesão domina como, por outro lado, um tipo de operário mais especializado, o técnico ${ }^{31}$, que controla conhecimentos e técnicas mais sofisticadas, o qual, inicialmente, era ainda raro no estado, devido exatamente às máquinas serem uma inovação, fato que levou alguns industrialistas a importá-los da Europa junto com as máquinas ${ }^{32}$.

As máquinas, além disso, propiciavam, através da divisão e simplificação das tarefas fabris e da consequente desvalorização desta função e salários, um crescimento numérico da mão de obra operária nestes espaços, bem como a significativa presença feminina e infantil, aos quais eram pagos baixos salários. Em 1916, na "Companhia Fiação e Tecidos PortoAlegrense" e na "Companhia Fabril Porto-Alegrense", altamente mecanizadas, havia o total de 300 operários, sendo 160 homens e 140 mulheres, e o salário médio diário era de $7 \$ 000$ para eles e de $4 \$ 000$ para elas. Já na segunda existiam 200 operários, 140 homens e 60 mulheres, e o salário médio diário era o mesmo pago na Cia. Fiação e Tecidos Porto-

\footnotetext{
${ }^{29}$ ERBER, op.cit, p. lii e PERROT, Op.cit., p. 24.

${ }^{30}$ Ver, por exemplo, O Proletário, Porto Alegre, 2/8/1896, p.2.

${ }^{31}$ Não desconheço a literatura que observa que este tipo de operário pode se auto-excluir da classe operária a partir do momento em que passa a defender, devido a sua posição ambígua no modo de produção - por se encontrar numa posição de supervisão fabril -, posicionamentos políticos e ideológicos afins com os interesses do capital. Ver POULANTZAS, Nicos. "As classes sociais". Estudos Cebrap. São Paulo: Ed. Brasileira de Ciências, 1973, n.3, pp.5-39.

${ }^{32}$ A historiografia local é farta em exemplos de empresas que, ao importarem suas máquinas, traziam com elas os técnicos, já que no estado eles eram inicialmente inexistentes. Ver, por exemplo, PESAVENTO, 1988, p. 33, p. 35-36.
} 
Alegrense para homens e mulheres ${ }^{33}$. A mão de obra infantil, por sua vez, era geralmente encontrada na indústria têxtil, do vestuário (roupas brancas, espartilhos e gravatas) e na de alimentos. Além das duas fábricas têxteis da capital citadas, esta mão de obra foi vista sendo utilizada na Companhia União Fabril de Rio Grande e na fábrica de roupas brancas, espartilhos e gravatas de Francisco Tanhauser (Porto Alegre). Faço notar, ainda, com relação a esta mão de obra, que a duração da sua jornada de trabalho não diferia da dos adultos ${ }^{34} \mathrm{e}$ que seus salários eram equivalentes ou inferiores aos femininos ${ }^{35}$.

Observo, contudo, que este processo de mecanização fabril relatado não significava a admissão "direta" da mão de obra feminina e, neste sentido, cabe introduzir uma comparação com outro contexto. Como demonstra Joan Scott em seu artigo "A mulher trabalhadora" ${ }^{36}$ - que trata da trabalhadora européia e norte-americana do séc. XIX -, a discriminação entre os gêneros que se faz presente, por exemplo, na hora de alocar preferencialmente as mulheres em funções de baixa remuneração, também se manifesta, e de forma primeira, através de uma divisão sexual do mercado de trabalho. Comenta a autora a esse respeito:

[Os empregadores] desenvolviam uma diversidade de estratégias para cortar os custos laborais. Instalavam máquinas, dividiam e simplificavam tarefas nos processos de fabrico, baixavam o nível e competência (e/ou formação e prática) requeridos para os seus empregados, intensificavam o ritmo e produção e reduziam os salários. Isto nem sempre significava admitir mulheres, pois havia muitos empregos considerados impróprios para elas e outros em que a resistência dos trabalhadores masculinos tornava impensável a contratação de mulheres. [...] [No universo europeu e norte-americano do século XIX] as mulheres eram associadas ao trabalho barato, mas nem todo trabalho barato era considerado apropriado para elas. Se eram consideradas aptas para trabalhar nos têxteis, na confecção, no calçado, no tabaco, na alimentação e na marroquinaria, raramente eram encontradas nas minas, na construção civil, na construção mecânica ou naval, mesmo quando havia a necessidade de mão de obra considerada 'não qualificada'. Um delegado francês à Exposição de 1867 descreveu claramente as distinções de

\footnotetext{
${ }^{33}$ Conforme Relatório ao Ex. Sr. Dr. Protásio Alves / Secretaria do estado dos Negócios do Interior e Exteriorpelo Diretor Interino Nathaniel Cunha (1916), op. cit.

${ }^{34}$ Ver notícia constante n' A Luta (19/07/1908, p.2) sobre esta indistinção na Fundição Alberto Bins.

${ }^{35}$ Isto é perfeitamente visível não só nas práticas dos industrialistas, como em matérias identificadas na imprensa operária e comercial do estado. Ver, para as práticas dos empresários, os Relatórios de Governo (SubIntendência do 4ㅇ distrito) e o da indústria Abramo Eberle, constantes em FAGUNDES, L. K. et al. Memória da indústria gaúcha (1899-1930). Porto Alegre: Editora da UFRGS / FEE, 1987, p. 133-143. Para a imprensa comercial, os dados que constam no Correio do Povo de 30/6/1911, p.1, e para a imprensa operária, os seguintes periódicos: A Luta, 15/12/1906, p.2; A Democracia, Porto Alegre: 30/12/1906, p. 3,4; 6/1/1907, p.3; 24/3/1907, p.2

${ }^{36}$ SCOTT, Joan. "A mulher trabalhadora". In: FRAISSE, G. \& PERROT, M. (org.) História das mulheres no Ocidente. Século XIX. Porto: Edições Afrontamento Ltda.1991. V. 4, pp. 442-475.

${ }^{36}$ Idem, ibidem, p. 453-460.
} 
acordo com o sexo, os materiais e as técnicas: 'Ao homem, a madeira e os metais. À mulher, a família e os tecidos' ${ }^{37}$.

Scott explica alguns contornos desta divisão sexual do mercado de trabalho europeu e norte-americano através de certas continuidades históricas no próprio conceito de trabalho feminino. Se no século XVIII as tarefas de agulha eram sinônimo de trabalho de mulher (como o da costureira), no século XIX, mesmo em um novo contexto da industrialização, aquelas tarefas continuavam na órbita feminina. Esta tradição nas "tarefas de agulha" tornava possível a presença da mulher nas indústrias têxteis, de vestuário e calçados (após a introdução de fios e o fim do uso de tachas na confecção).

Além disso, tarefas que requeriam dedos delicados e ágeis, paciência e perseverança, eram também consideradas como da "natureza feminina". Daí a presença da mulher em indústrias alimentícias e de bebidas. Também, conforme Scott, embora o trabalho feminino fosse mal remunerado, nem todo ele era desqualificado. Pode-se, neste sentido, ser ainda mais

interpelativo na análise e questionar se há, de fato, uma não qualificação do trabalho feminino, mesmo em fábricas altamente mecanizadas. Como afirma Danièle Kergoat, a aparente não qualificação feminina, expressa em tarefas manuais simples que a mulher pretensamente realiza graças à sua 'natureza feminina' (destreza manual, paciência etc.), é, na realidade, fruto de habilidades adquiridas pela mulher na sociedade moderna, ao longo de toda uma vida associada às atividades reprodutivas: ser mãe, ser dona de casa e ter habilidades domésticas etc. ${ }^{38}$

O trabalho dos homens, por sua vez, segundo Scott, era associado neste contexto à força muscular e à velocidade, sendo reconhecida como 'natural' a presença masculina nas funções em que os músculos eram requeridos, como nas minas, na construção naval,

\footnotetext{
${ }^{37}$ SCOTT, op.cit., p.453.

${ }^{38}$ KERGOAT, D. Les ouvrières. Paris: Le Sycomore, 1982, p. 55-56. Aqui acompanho uma bibliografia que relativiza e até, em alguns casos, invalida as compreensões de época e tendências historiográficas que entendem ser o trabalho da mulher operária pouco qualificado. Menciono como exemplos os trabalhos de: KERGOAT, Daniele. Les ouvrières. Paris: Le Sycomore, 1982; LE DOARÉ, Hélène. "Divisão sexual e divisão internacional do trabalho: reflexões a partir das fábricas subcontratadas de montagem (México-Haiti)". In: KARTCHEVSKY-BULPORT, A. et al. O sexo do trabalho. Rio de Janeiro: Paz e Terra, 1987; RODRIGUES, Arakcy Martins. "Lugar e imagem da mulher na indústria". In: BRUSCHINI \& COSTA (org.) Uma questão de gênero. Rio de Janeiro: Rosa dos Tempos; São Paulo: Fundação Carlos Chagas, 1992.
} 
mecânica e civil; bem como o entendimento de que o trabalho masculino era mais qualificado e de maior valor que o feminino ${ }^{39}$.

No Rio Grande do Sul, pelo que se identificou, não se fugiu muito ao juízo proferido pelo delegado francês, e resgatado por J. Scott, durante a grande exposição industrial de 1867: “Ao homem, a madeira e os metais. À mulher, a família e os tecidos" ${ }^{40}$.

Através do levantamento realizado mediante a documentação consultada, verificouse que no Rio Grande do Sul das primeiras décadas do século XX a mulher estava presente na indústria têxtil, de vestuário, calçados, cigarros e charutos, fósforos e alimentícia.

\begin{tabular}{|l|l|}
\hline Têxtil e vestuário & $\begin{array}{l}\text { Porto Alegre: Fábrica de Meias A. J. Renner; Cia. Fiação e Tecidos Porto- } \\
\text { Alegrense; Cia. Fabril Porto-Alegrense; Fábrica de Tecidos e Fiação } \\
\text { Oscar Schaitz, de J. Papst \& Cia.; Francisco Tanhauser; F. C. Kessler \& } \\
\text { Comp.; e várias pequenas oficinas de costura. }\end{array}$ \\
$\begin{array}{ll}\text { Pelotas: Tecelagem Ítalo-Brazileira; Companhia União Fabril; Fábrica de } \\
\text { Chapéus Pelotense ; Companhia Fiação e Tecidos Pelotense. } \\
\text { Rio Grande: Companhia União Fabril; Tecelagem Ítalo-Brazileira. }\end{array}$ \\
\hline $\begin{array}{l}\text { Alimentícia } \\
\text { Cigarros } \\
\text { Charutos }\end{array}$ & $\begin{array}{l}\text { Pelotas: Fábrica Aliança; Leal, Santos \& Cia.; Cervejaria Sul- } \\
\text { Riograndense. } \\
\text { Rio Grande: Leal, Santos \& Cia.; Estabelecimento de Túlio Martins de } \\
\text { Freitas; Moinho Rio-Grandense. } \\
\text { São Sebastião do Caí: Oderich \& C. }\end{array}$ \\
\hline $\begin{array}{l}\text { Perfumaria } \\
\text { medicamentos }\end{array}$ & $\begin{array}{l}\text { Porto Alegre: Estabelecimento de H. Rodhe. } \\
\text { Pelotas: Fábrica São Rafael. } \\
\text { Rio Grande: Fábrica de charutos havanezes e nacionais Poock \& Comp. }\end{array}$ \\
\hline Fósforos & $\begin{array}{l}\text { Porto Alegre e Pelotas: Estabelecimentos de Adolpho Voight, de F. C. } \\
\text { Lang \& Cia.; } \\
\text { Pelotas: Estabelecimento Industrial Pharmaceutico Souza Soares. }\end{array}$ \\
\hline Calçados & $\begin{array}{l}\text { São Leopoldo: Sul Rio-Grandense. } \\
\text { São Leopoldo: Fábrica de Calçados Sul Rio-Grandense. }\end{array}$ \\
\hline
\end{tabular}

Mesmo não tendo sido identificadas todas as tarefas desempenhadas pelas mulheres nas indústrias de tecido, de vestuário e de calçado, elas foram encontradas exercendo atividades que requeriam habilidades com fios e agulhas: eram costureiras ${ }^{41}$ e tecelãs ${ }^{42}$.

\footnotetext{
${ }^{39}$ SCOTT, J.,1991, Op.cit. p. 460.

40 Idem, Ibidem, p. 453.

${ }^{41}$ Como costureiras na indústria têxtil: Cia. Fabril Porto-Alegrense e na Companhia União Fabril (Rheingantz) de Rio Grande. Ver A Gazetinha, Porto Alegre: 5/3/1896, p.4 e 21/9/1898, p.2; Echo Operário, Rio Grande, 24/7/1898, p.4; A Luta, Porto Alegre, 15/12/1906, p. 2. Na indústria do vestuário; roupas brancas, gravatas, espartilhos e chapéus (em várias pequenas oficinas do estado como em fábricas), ver: A Gazetinha, Porto Alegre: 5/3/1896, p. 4, 22/8/1897, p. 3; Correio do Povo, Porto Alegre: 24/6/1900, p. 4, 5/6/1911, p. 1, 12/5/1911, p. 5, 30/6/1911, p. 1, 28/8/1912, p. 9, 1/11/1912, p. 1 . A Democracia, Porto Alegre: 28/2/1907, p. 2, 14/2/1907, p. 2. Echo Operário, Porto Alegre, 24/9/1908, p. 1. Na indústria de calçados também ocupavam a
} 
Ainda que várias tenham sido as referências encontradas sobre o emprego de mulheres como tecelãs, observei, contudo, a existência de homens também nesta função, mas, no entanto, não foi possível saber se ambos exerciam atividades distintas.

Já na indústria de cigarros, de charutos e de fósforos, as mulheres foram encontradas em funções que requeriam destreza manual: eram empacotadoras (enchimento de caixas com fósforos) ${ }^{43}$, enroladoras de cigarros e charutos. Na Fábrica de charutos havanezes e nacionais Poock \& Comp. (a maior no gênero da época), localizada em Rio Grande, por exemplo, todo o trabalho era feito exclusivamente pelas mulheres, e manualmente, já que não havia maquinismos na produção ${ }^{44}$.

$\mathrm{Na}$ indústria alimentícia, por sua vez, as informações mais precisas revelam que na Fábrica Aliança de Pelotas, as mulheres trabalhavam na $1^{\underline{a}}$ seção desta fábrica, a que fazia conservas de carne, peixe, frutas e legumes. $\mathrm{Na} 2^{a}$ seção, que produzia charque e banha, só homens trabalhavam ${ }^{45}$.

Embora nem sempre tenha encontrado referências diretas sobre o emprego específico de homens em determinadas áreas da produção ${ }^{46}$, observei que essa ausência de informações ocorria nos documentos quando se tratava de ramos de atividade associados a determinados ofícios de tradição masculina, como marcenaria, funilaria, carpintaria, tipografia, litografia, metalurgia, oficinas mecânicas e fundições. Destaco que muitos meninos já eram mencionados como executores de serviços que "respeitavam" esta linha demarcatória do que era tido como trabalho de homem e de mulher. Muitos eram ajudantes ou aprendizes em oficinas de tipografia, calçados e carpintaria; trabalhavam em fundições e

função de costureiras, como se vê a partir do seguinte anúncio: "Precisa-se de 30 montadores, 2 cortadores e de costureiros e costureiras na Fábrica de Calçados Sul Rio-Grandense, de Pedro Adams Filho. São Leopoldo" Ver Correio do Povo, Porto Alegre, 13/10/1912, p. 2. Sobre o emprego da mulher como costureira na indústria de calçados, ver também: A Gazetinha, Porto Alegre, 17/10/1897, p. 2, O Diário, Porto Alegre, 26/9/1911, p. 5 e Correio do Povo, Porto Alegre, 12/4/1914, p. 22. Sobre o emprego do homem como cortador, montador e acabador de sapatos nesta mencionada indústria, ver: Correio do Povo, Porto Alegre: 17/2/1899, p. 3 e 2/2/1901, p. 1.

42 Echo Operário, Rio Grande, 18/9/1897, p. 4; A Democracia, Porto Alegre, 13/8/1905, p. 3; Correio do Povo, Porto Alegre, 29/3/1901, p. 2; 4/7/1911, p. 8.

${ }^{43}$ Avante, Porto Alegre, 24/6/1908, p. 3.

${ }^{44}$ Conforme também anúncio que relata a existência de vagas para "boas cigarreiras para manufaturar os cigarros pérolas, senadores e conquistadores" ver A Democracia, Porto Alegre, 28/2/1907, p. 4. Ver ainda a exigência desta precisão manual para a função de cigarreira no Correio do Povo, Porto Alegre, 12/5/1911, p. 1; 12/4/1914, p. 1; 17/12/1913, p. 14 e O Diário, Porto Alegre, 19/5/1912.

${ }^{45}$ O Rio Grande do Sul industrial. Porto Alegre: Echenique, 1907.

${ }^{46}$ As referências mais diretas obtidas foram em anúncios de jornais - operários ou não - que informavam sobre ofertas de trabalho. Ver, por exemplo, A Democracia, Porto Alegre, 24/1/1907, p. 4; 28/2/1907, p. 4. Correio do Povo, Porto Alegre, 29/3/1901, p. 2; 4/7/1911, p. 8. O Diário, Porto Alegre, 13/10/1911, p. 2. 
estaleiros, para citar alguns exemplos ${ }^{47}$. É importante aqui salientar que esta não referência direta pode ser entendida como um tipo de discurso que revela o que era tido como impensável para as mulheres enquanto exercício de um ofício ou trabalho profissional. Ou seja, pedir-se um marceneiro, um tipógrafo, um funileiro etc. era o mesmo que solicitar um homem para o exercício dessas funções até então indiscutivelmente masculinas.

Abaixo segue um quadro dos estabelecimentos encontrados para o Rio Grande do Sul que desenvolviam atividades tidas tradicionalmente como do gênero masculino. Em outras palavras, estes eram estabelecimentos do Estado em que os operários homens eram maciçamente majoritários.

\begin{tabular}{|c|c|c|}
\hline $\begin{array}{l}\text { Tipografias } \\
\text { Litografias }\end{array}$ & e & $\begin{array}{l}\text { Porto Alegre: Estamparia Hirtz \& Irmãos. } \\
\text { Pelotas: Echenique \& Comp.; Oficina de Litografia do Estabelecimento } \\
\text { Industrial Pharmacêutico Souza Soares (medicamentos). } \\
\text { Rio Grande:.Estamparia Rio-Grandense; Lopes \& Faral; Oficina de } \\
\text { Litografia da Fábrica Leal, Santos \& Cia. (conservas). }\end{array}$ \\
\hline $\begin{array}{l}\text { Fábricas } \\
\text { Móveis, } \\
\text { Carpintarias } \\
\text { Marcenarias }\end{array}$ & & $\begin{array}{l}\text { Porto Alegre: Carpintaria Porto-Alegrense Germano Steigleder Sob.; } \\
\text { Fábricas de móveis de Arbos \& Salvador, de Kappel \& Arnt, de Francisco } \\
\text { Herzog e de Walter Gerdau; Oficinas de carpintaria da Fábrica H. Ritter } \\
\text { \& Irmãos (conservas) e de Jorge R. Petersen (escovas). } \\
\text { Pelotas: Oficinas de carpintaria da Fábrica de Chapéus Pelotense, da } \\
\text { Empresa Domingos José de Oliveira (sabonetes e essências), da Fábrica } \\
\text { Aliança (conservas), da Empresa Christiá \& Comp. (vinhos e licores) e } \\
\text { do Estabelecimento Industrial Pharmacêutico Souza Soares. } \\
\text { Rio Grande: Oficinas de carpintaria da Fábrica Companhia União Fabril } \\
\text { (Têxtil), da Empresa Túlio Martins de Freitas (conservas) e da Fábrica } \\
\text { Leal, Santos \& Cia. }\end{array}$ \\
\hline $\begin{array}{l}\text { Fundições, } \\
\text { Metalúrgicas } \\
\text { Serralherias }\end{array}$ & e & $\begin{array}{l}\text { Porto Alegre: Fundição Alberto Bins; Metalúrgica de Victor H. da Silva; } \\
\text { Empresa Wallig \& Comp.; Oficinas de funilaria das fábricas Nicoláo } \\
\text { Greco \& Cia. (banha), Rodolpho França, Neugebauer Irmãos (doces); } \\
\text { Oficinas de serralheria das Fábricas de H. Ritter \& Irmãos (conservas); } \\
\text { de Jorge R. Petersen e de Túlio Martins de Freitas (conservas). } \\
\text { Pelotas: Oficina de ferraria e serralheria da Fábrica de chapéus } \\
\text { Pelotense e da Fábrica Aliança. } \\
\text { Rio Grande: Oficina de máquinas de Augusto José Dias; Oficinas de } \\
\text { fundição e serralheria das Fábricas Companhia União Fabril e Leal, } \\
\text { Santos \& Cia. (conservas). }\end{array}$ \\
\hline Ola & & $\begin{array}{l}\text { do Rio dos Sinos). } \\
\text { Stanisci (Pelotas). }\end{array}$ \\
\hline Outrc & & $\begin{array}{l}\text { Estaleiro José Becker \& Irmão (Porto Alegre); Oficina de Carruagens } \\
\text { Luiz Rothfunchs \& Irmãos (Porto Alegre); Curtume Mario Ribeiro (Rio } \\
\text { Grande); Oficina de Estatuária e Mosaicos de João Vicente Friederichs } \\
\text { (Porto Alegre). }\end{array}$ \\
\hline
\end{tabular}

${ }^{47}$ Conforme dados constantes, por exemplo, no Correio do Povo, Porto Alegre: 11/3/1899, p. 2; 24/1/1901, p. 1; 9/2/1915, p. 4; e n'A Luta, Porto Alegre, 19/7/1908, p. 2. 
Estabelecendo um paralelo entre os salários femininos e masculinos, constatei uma grande oscilação de valores, ainda que o salário das operárias fosse o mais baixo. No quadro abaixo, elaborado a partir do "Relatório Apresentado ao Ex. Sr. Dr. Protásio Alves, pela Secretaria do Estado dos Negócios do Interior e Exterior", em 1916, fica clara esta discriminação ${ }^{48}$ :

\begin{tabular}{|l|l|l|}
\hline EMPRESA & HOMENS & MULHERES \\
\hline Cia. Fiação e Tecidos Porto-Alegrense & $7 \$ 000$ & $4 \$ 000$ \\
\hline Cia. Fabril & $7 \$ 000$ & $4 \$ 000$ \\
\hline Fábrica de Tecidos e Fiação - Oscar Schaitz e Cia. & $4 \$ 000$ & $2 \$ 500$ \\
\hline Fábrica de Meias A. J. Renner e Cia. & $4 \$ 000$ & $2 \$ 000$ \\
\hline
\end{tabular}

A mão de obra feminina, por ser de menor remuneração, era também empregada pelos empresários a fim de maximizar seus lucros, de forma concorrente à mão de obra masculina. Apesar da existência de matérias na imprensa operária que sugerem ser esta prática uma ação generalizada, os dados aí levantados revelam que esta ação se dava na área da produção onde as tarefas eram tidas como compatíveis com a "natureza feminina": na indústria têxtil ${ }^{49}$ e nas atividades de costura. É ilustrativo deste caso o artigo do jornal Echo Operário de Rio Grande, escrito por um ressentido alfaiate, que clama pelo fim da concorrência com as costureiras e pela justeza de um salário mais alto para sua categoria profissional:

À classe dos alfaiates

Quem vos dirige a palavra escrita neste momento, desejaria poder fazê-lo a um por um, para assim convencer-se de que não têm nesta cidade colegas capazes de unirem-se na defesa dos direitos como lhe dizem e como lhe parece impossível. Chegado [ilegível] a esta cidade fui surpreendido com a notícia que me deram que não há [ilegível] alfaiates associados em grêmio [ilegível] operário, e que, entretanto a nossa classe é uma das mais sacrificadas pelos preços mesquinhos que recebe pelas peças de obra já pela competência que nos fazem as costureiras a quem patrões sem escrúpulo entregam trabalhos menos importância mas que deveriam ser dadas aos oficiais para que de qualquer forma compensarem o nosso trabalho geralmente trabalhoso e de fazendas ruins de trabalhar.

\footnotetext{
${ }^{48}$ Maiores informações a respeito, vide ARAVANIS, Evangelia. O corpo em evidência nas lutas dos operários gaúchos. Porto Alegre, IFCH/UFRGS: 2005, pp.88-95.

${ }^{49}$ Conforme o Echo Operário, 7/11/1897, p. 1, de Rio Grande, "na fábrica ítalo-brasileira sabemos que dão preferência ao pessoal feminino pelo masculino! Não vamos dizer que seja isso por espírito de altruísmo, humanitário e social; pois que se dali não lhes viesse vantagem, eles não se lembrariam de fazer preferências; a vantagem está em que as mulheres sujeitam-se mais a explorações que os homens, por trabalharem sempre mais barato que estes".
} 
Segundo me consta a já alguns anos que isto se dá e ainda não houve um protesto por parte dos oficiais e alfaiate!

Pois bem, eu apelo para os nossos interesses e para a nossa dignidade de artistas para que nos unamos na União Operária e daí estudarmos o melhor modo de evitar essa guerra que nos fazem as costureiras que se sacrificam a si, desgraçando-nos a nós.

Bem sabemos que é a miséria a causa dessa guerra; mas se elas podem ganhar mais sem guerrear-nos, basta que nós nos unamos, por que não havemos de fazêlo? Elas geralmente têm quem as sustente, apenas trabalham para auxiliar os maridos, por isso qualquer coisa lhes serve; mas nós que não temos outro recurso devemos buscar guerrear este sistema de competência, travando uma campanha de descrédito as casas que assim exploram a freguesia e a nós.

Amandio Christo ${ }^{50}$

Com relação às lógicas que norteavam esta forma de disposição "generada" do mercado de trabalho fabril, observo, com base no que foi exposto, que o trabalho feminino era entendido como compatível às tarefas que exigiam dedos delicados e ágeis, certa paciência, lida com alimentos e fios e agulhas, e que não necessitavam, obrigatoriamente, da força muscular. Já com relação ao trabalho masculino, os músculos, o "perigo" (locais com a presença do ferro e do fogo) e o trabalho "pesado" (trabalho com a madeira, com a pedra etc.) eram o mote. Os locais indiscutíveis de trabalho dos homens eram as marcenarias, as fundições, as funilarias, os estaleiros, as tipografias etc.

Sobre essas lógicas apresentadas, bem como sobre a divisão sexual fabril exposta, é pertinente observar que elas não são inéditas, mas recorrentes na Europa ocidental dos primórdios da industrialização, conforme apontado por Joan Scott, o que parece acompanhar uma tendência geral no mundo fabril, considerando-se os dados trazidos por Maria Valéria Junho Pena para os principais pólos fabris do Brasil do início do século XX, São Paulo e Rio de Janeiro:

[...] em 1920, as mulheres compunham [em São Paulo e Rio de Janeiro] a maioria absoluta de operariado no têxtil, em certos ramos de confecção (camisas, roupas, chapéus para senhoras, fitas e cadarços, roupas pra homens, redes, flores artificiais, chapéus de pano e bonés, chapéus de palha, rendas e bordados), na produção de fumos, cigarros, charutos, de caixas de papelão, fósforos, perfumarias e chocolates. [...] Mecânica, metalurgia, construção civil, produção e distribuição de água, gás e eletricidade, curtume e editorial e gráfica praticamente desconheciam a presença de trabalhadoras mulheres ${ }^{51}$.

Como se pode perceber, ainda que se encontrassem "abertas" as portas para o ingresso maciço das mulheres no mundo fabril do trabalho, este processo foi matizado por

\footnotetext{
${ }^{50}$ Echo Operário, 18/12/1898, p. 3.

${ }^{51}$ PENA, Maria V. Junho. Mulheres e trabalhadora: presença feminina na constituição do sistema fabril. Rio de Janeiro: Paz e Terra, 1981, pp. 140-141
} 
sua condição de gênero. Havia certas lógicas de gênero que claramente organizavam o mercado de trabalho fabril no estado, colocando as mulheres em algumas ocupações e funções e não em outras, o que valia também para os homens. Ou seja, as relações entre os gêneros matizavam e determinavam as próprias relações produtivas capitalistas.

No caso aqui específico, o que se vê é o reforço de funções tidas como naturais à mulher no período - a delicadeza, a paciência, a agilidade manual, a lida com alimentos e fios e agulhas -, qualidades que, na verdade, são fruto de toda uma trajetória feminina vinculada às atividades domésticas e reprodutivas (ser mãe, dona de casa e esposa), modelos do feminino à época ${ }^{52}$.

Já com relação aos homens pode-se apontar a presença desta matização histórica de gênero como resultado do fato de o espaço público ser, no período, um "mundo" entendido como eminentemente masculino. Como se percebe a este respeito, o homem exerce funções relacionadas a valores positivos de construção da masculinidade à época: força, virilidade e coragem.

Em resumo, no Rio Grande do Sul não se fugiu muito ao juízo proferido pelo já mencionado delegado francês à grande exposição industrial de 1867: “Ao homem, a madeira e os metais. À mulher, a família e os tecidos", fato este que parece acompanhar uma tendência geral no mundo fabril, conforme se deduz das análises de Joan Scott para a Europa e os EUA, do século XIX para o XX, e de Pena para os principais polos industriais do Brasil à época.

Em seu artigo "A dominação masculina", Pierre Bourdieu afirma que os gêneros se estruturam a partir de uma oposição binária entre o "mundo exterior" (o trabalho com fogo, perigoso; não vinculado à procriação, o oficial, o visível, o socialmente reconhecido etc.), que corresponde ao masculino, e o "mundo interior" (a casa, a família etc.), que corresponde ao feminino, atribuindo, além disto, nesta estrutura binária, uma posição hierárquica superior ao primeiro pólo ${ }^{53}$.

\footnotetext{
${ }^{52}$ A bibliografia a respeito desse modelo do feminino é extensa. Cito somente algumas obras a título de referência: RAGO, Margareth."Relações de Gênero e classe operária no Brasil, 1890-1930." In: Caderno Espaço Feminino. Minas Gerais: Ed. Universidade Federal de Uberlândia, 1998; COSTA, Jurandir F. Ordem médica e norma familiar. Rio de Janeiro: Edições Graal, 1989; PERROT, Michelle. "Figuras e papéis". In: ARIÉS \& DUBY. História da vida privada: Da revolução à Primeira Guerra. São Paulo: Cia das Letras, 1994.

${ }^{53}$ BOURDIEU, Pierre “A dominação masculina”. In: Educação \& Realidade. Porto Alegre: EDUFRGS, 1995. V. 20 no 2. Jul./dez. 1995, p. 137-141.
} 
Sem pretender assumir, em sua totalidade, o quadro analítico destas oposições entendidas como estruturalmente vigente entre os gêneros - o que, sem o devido confronto com a realidade, pode acarretar uma interpretação reinstituidora de concepções essencialistas -, acredito que esse autor oferece elementos que contribuem para o entendimento da forma de ingresso da mulher no mundo público do trabalho. Observo, nesta perspectiva, que quando a mulher ingressa no espaço externo/masculino isto não ocorre sem a marca do pólo dominante. Em outras palavras, sua ida ao mundo público/exterior do trabalho se dava "por baixo", pois de forma mal remunerada e de acordo com aquilo que era entendido como do "frágil" universo feminino à época.

Bourdieu, em seu já citado artigo, expõe o que chama de uma "somatização das relações de dominação", demonstrando que o "mundo social" confere um "golpe de força sobre cada um de seus sujeitos", imprimindo nos corpos "um verdadeiro programa de percepção, apreciação e ação que, na sua dimensão sexuada e sexuante, como em todas as outras, funciona como uma natureza (cultivada/segunda)" ${ }^{\prime 54}$. Em outras palavras, pode-se afirmar que o Capital vinha impondo um "golpe de força" sobre os corpos dos operários no Rio Grande do Sul daqueles anos, transformando-os naquilo que o sistema fabril exigia para cada um dos gêneros. Os industrialistas necessitavam, para o exercício dos trabalhos fabris em questão, de corpos masculinos com desenvoltura física dos braços (braços fortes) e de operárias com dedos e braços ágeis. Ou seja, para os homens, a desenvoltura da força muscular; já para as mulheres, a destreza e a habilidade manual fina.

A figura do operário musculoso trabalhando na máquina e a da operária pacienciosa e manualmente ágil na lida em um tear, frequentemente divulgados pelas publicações da época, são bem emblemáticas da exigência - e da existência - destes corpos em questão. Esta exigência, observo, também era um elemento que realimentava um quesito social do período com relação aos valores e aos "tipos" de corpos que homens e mulheres deveriam buscar adquirir. Se com os homens os corpos deveriam conter a força e a coragem (refletindo o "lado" frio e racional do homem), à mulher as qualidades e atributos corporais deveriam ser a fragilidade e a delicadeza ${ }^{55}$.

\footnotetext{
${ }^{54}$ BOURDIEU, P., op.cit., p.145.

${ }^{55}$ Ver a respeito: SANT'ANNA, Denise B. Políticas do Corpo. São Paulo: Estação Liberdade, 1995; PRIORE, Mary Del. Corpo a corpo com a mulher: pequena história das transformações do corpo feminino no Brasil. São Paulo: Editora SENAC, 2000.
} 
Tratando agora das condições de higiene e da segurança nas fábricas, ressalto que a documentação que mais trouxe elementos foi a imprensa, principalmente a comercial.

Através de uma série de artigos nela publicados e que revelavam um certo fascínio com a tecnologia destes novos tempos, observei que alguns industriais no estado, como os proprietários da Fábrica Alberto Bins, da Cervejaria Bopp, da Fábrica de calçados GodiarWell e a de chapéus F.C. Kessler e Cia. ${ }^{56}$, ao iniciarem sua sintonia com aquilo que veio a ser conhecido como taylorismo, faziam de suas fábricas locais mais higiênicos, produtivos e seguros $^{57}$. A fábrica era apresentada, pelos "jornalistas" que visitavam as novas ou reformadas fábricas do estado, a convite destas, como um espaço cientificamente construído, onde havia boa iluminação e ventilação, água potável, amplos espaços e máquinas facilitando o trabalho humano; enfim, como local próprio e agradável para o trabalho ${ }^{58}$.

Na fábrica de chapéus de F. C. Kessler e Cia., fundada em 1901, por exemplo, os "preceitos da higiene fabril" haviam sido respeitados ao se estabelecer "em todas as seções um bom sistema de ventilação por meio de ventiladores e exaustores especiais e da acertada colocação das portas e janelas, as quais distribuem luz de forma conveniente"59. Já no novo edifício, inaugurado em 1911, da Fábrica de cerveja e gelo Bopp \& Irmãos, fundada em 1881, "teriam sido empregados os melhores, os mais adequados materiais e cuidados com [...] a distribuição do ar e da luz", e seus "pisos impermeáveis e as paredes de cimento armado permitem a mais rigorosa limpeza" $"$.

Na Fábrica Alberto Bins, para citar ainda mais exemplos, tem-se o relato de que a "água para os operários é filtrada e encanada em todo o estabelecimento"61 ; e na Fábrica de chapéus de F. C. Kessler e Cia., havia “dois grandes depósitos de água, de cimento,

\footnotetext{
${ }^{56}$ O Diário, Porto Alegre: 29/10/1911, p.14; 08/04/1912, p.5; 27/04/1913, p.18 e Correio do Povo, Porto Alegre, 28/08/1912, p.5, 6 .

${ }^{57}$ Conforme Margareth L. Rago: “A representação da 'nova fábrica', que o estado e os médicos defendem perante os industriais [em São Paulo], já fora anunciada, desde o final do século anterior, nos Estados Unidos, por Frederick W. Taylor [...] e por seus discípulos. Pretendia eliminar e contrapor-se à imagem da 'fábrica satânica', escura e fétida, detestada pelos trabalhadores, que se sentiam sugados em todas as suas energias para realizar o objetivo particular e individualista dos patrões" Ver RAGO, op.cit, 1997, p. 38-39. Para outras informações mais detalhadas sobre as teorias e métodos tayloristas e de suas aplicações em diferentes realidades, ver: RAGO, L. M. \& MOREIRA, E. O que é taylorismo. São Paulo: Brasiliense, 1984; TAYLOR, Frederick W. Princípios da Administração Científica. São Paulo: Atlas, 1982.

${ }^{58}$ O Diário, Porto Alegre, 27/4/1913, p. 18; Echo do Povo, Porto Alegre, 30/11/1911, p. 1 e Correio do Povo, Porto Alegre, 28/8/1912, p. 5, 6.

${ }^{59}$ O Diário, Porto Alegre, 27/4/1913, p. 18.

${ }^{60}$ Correio do Povo, Porto Alegre, 28/8/1912, p. 5.

${ }^{61}$ O Diário, Porto Alegre, 24/10/1911, p. 14.
} 
hermeticamente fechados, com os seus correspondentes filtros Bergefeledt e que fornecem aos operários um líquido fresco e isento de impurezas. Á água dos filtros [era] fornecida pela hidráulica, e não pelo reservatório do estabelecimento, pois esta última era empregada nas máquinas e outros misteres de trabalho"62.

Já com relação à segurança fabril, a construção de amplos espaços como local de trabalho é reveladora da preocupação de se evitar acidentes, por estes industrialistas. Conforme se pode inferir a este respeito da seguinte informação sobre a "Companhia Fiação em Tecidos": “A área ocupada pelas fábricas e duas dependências é de $9.300 \mathrm{~m} 2$ [...] possuindo a Companhia para futuras construções, uma área de mais de 20.000 [m2] [...]. Seus edifícios são de sólida e elegante construção, e na instalação dos maquinismos foram guardados os espaços para os operários trabalharem desembaraçadamente"63.

Por outro lado, também observei que esses industriais, através do investimento na tecnificação, visavam aumentar a quantidade e a qualidade de seus produtos. Um ilustrativo caso a respeito é visível através de vários anúncios de venda de máquinas para panificação (as amassadoras de pão), nos quais se afirma que estas, além de imitarem a ação humana e serem "bem mais rápidas", substituem "o antigo e anti-higiênico serviço braçal"64. Em suma, gestavam-se no estado fábricas de um "novo tempo", em que a disciplina, agora, era cada vez menos imposta pelos mestres e contramestres, e sim por maquinismos cada vez mais complexos (alguns já movidos a eletricidade), por um gerenciamento técnico-científico da produção e pela construção de uma nova subjetividade operária no e do espaço fabril.

Noto, no entanto, que toda esta preocupação de alguns industriais em modificar o perfil de suas fábricas não permite concluir que as unidades produtivas no período em estudo no Rio Grande do Sul, como um todo, tinham ou iriam ter as melhorias apontadas, até porque tanto continuavam a existir as pequenas fábricas e oficinas de "fundo de quintal", estabelecidas, certamente, sem tal preocupação ${ }^{65}$, quanto as chamadas "fábricas higiênicas", para utilizar a conhecida expressão de Margareth Rago.

\footnotetext{
62 O Diário, Porto Alegre, 27/4/1913, p. 18.

${ }^{63}$ Ver Impressões do Brasil no século XX, s.n.t. apud PESAVENTO, S. 1988, op. cit., p. 30.

${ }^{64}$ Correio do Povo, Porto Alegre, 30/11/1912, p. 1. Ver também o relato de aumento da produção de chapéus na Fábrica de F. C. Kessler e Cia., devido à renovação do maquinário: O Diário, Porto Alegre, 27/4/1913, p. 18 e os cuidados no preparo da cerveja pela Cervejaria Bopp: Correio do Povo, Porto Alegre, 28/8/1912, p. 5,6.

${ }^{65}$ Ver a este respeito, por exemplo, os dados constantes no Correio do Povo, Porto Alegre, 7/10/1913, p. 10 e $n^{\prime} O$ Diário, Porto Alegre, 26/9/1911, p. 5. No primeiro caso, tratava-se de um atelier de costura estabelecido junto à casa de moradia, e no segundo, de uma pequena oficina de fabricação de chinelos que funcionava na própria casa do patrão - conforme se deduz do anúncio que alertava que para ali se empregar era necessário "se sujeitar a trabalhar em casa de família". Ambas as oficinas se encontravam localizadas em Porto Alegre.
} 
llustrando, para a época, a presença das "fábricas satânicas", menciono que não foram poucas as denúncias na imprensa operária e comercial sobre a insalubridade existente em alguns destes locais de trabalho ${ }^{66}$. Um outro testemunho desta realidade insalubre, só que de forma indireta, é a "Disposição de Tese" elaborada em 1918 pelo Deputado Federal pelo estado do Rio Grande do Sul, o médico Carlos Penafiel, para servir de base à criação de um anteprojeto de lei sobre "Higiene e Segurança do Trabalho". Neste documento vê-se claramente a preocupação de obrigar os industrialistas a dotarem seus estabelecimentos de boa iluminação solar e de aparelhos que renovassem o ar, a fim de evitar, neste último caso, a presença ali de gases e de poeiras nocivas à saúde ${ }^{67}$.

Apesar de não ter podido quantificar a extensão desta realidade no estado, as fontes enunciam, com ênfase, a insalubridade nos seguintes estabelecimentos fabris, todos de Porto Alegre: a Cia. Fiação e Tecidos Porto-Alegrense, a Cia. Manufatureira, a Fábrica Alberto Bins, a Fábrica Oscar Teichmann e a $2^{a}$ oficina do jornal $A$ Federação ${ }^{68}$. Sobre esta última, vale a pena transcrever um trecho da crítica veemente às condições de higiene enfrentadas pelos cerca de 20 homens que aí trabalhavam:

[...] e como se tudo isso ainda não fosse suficiente para abalar, para destruir a saúde do pessoal operário d'A Federação, acresce mais este caso barbaramente anti-higiênico: não há latrinas no edifício!

Quem penetra nas oficinas sente logo um odor bem desagradável: é provavelmente de um tanque existente a um canto e que serve de mictório e para as lavagens.

Disseram-nos, não há muitos dias, que agora aquilo é um melhoramento; outrora servia de mictório uma imunda lata que era, depois de bem cheia, despejada, à noite, na calha fronteira a casa ${ }^{69}$.

A insalubridade que empestava os citados locais devia-se a fatores de ordem diferenciada, fatores que não necessariamente se manifestavam de forma individual nestes locais. Encontrou-se o descaso com a higiene/o "asseio" ${ }^{70}$; a permissão da presença do

Observo, ainda, nesta perspectiva, que não raro na imprensa diária da capital via-se oferta de aluguel de casas onde, no térreo, poderia ser aberta, conforme o anúncio, uma pequena oficina. Ver, por exemplo, anúncio $n^{\prime} O$ Diário, Porto Alegre, 25/2/1915, p. 2.

${ }^{66}$ Ver O Diário, Porto Alegre, 29/10/1911, p. 4; Correio do Povo, Porto Alegre, 5/3/1913, p. 4; A Federação, Porto Alegre, 2/2/1892; A Democracia, Porto Alegre, 4/6/1905, p. 1-2; 4/8/1907, p. 2; A Luta, Porto Alegre, 13/9/1906, p. 2; 19/7/1908, p. 1,2 .

${ }^{67}$ Esta "tese" encontra-se reproduzida nos Anais do 9o Congresso Médico Brasileiro (1926), como fruto de sua apresentação por C. Penafiel no evento.

${ }^{68}$ Ver A Luta, Porto Alegre, 13/9/1906, p. 2; A Federação, Porto Alegre, 2/2/1892; O Diário, Porto Alegre, 29/10/1911, p. 14; A Luta, Porto Alegre, 19/7/1908; A Democracia, Porto Alegre, 4/8/1907; 4/6/1905, p. $1-2$.

${ }^{69}$ A Democracia, Porto Alegre, 4/6/1905, p. 2.

${ }^{70}$ A Federação, Porto Alegre,2/2/1892 e A Democracia, 4/6/1905, p. 2. 
álcool nos estabelecimentos ${ }^{71}$; a inadequada estrutura física dos prédios (sem banheiros ou com estes colocados em locais próximos aos locais de trabalho) ${ }^{72}$; falta de filtros nos reservatórios d'água ${ }^{73}$; janelas com iluminação inadequada e a presença de máquinas "ensurdecedoras"74.

Um outro indicativo da existência de estabelecimentos fabris do "tipo satânico" é o fato de ocorrerem vários acidentes nestes locais, inclusive com mulheres e crianças ${ }^{75}$. Muitos destes acidentes, se não levaram à morte, deixaram marcas trágicas nos corpos em questão: as mutilações. Via de regra, eram os dedos, mãos e braços as partes atingidas:

\begin{abstract}
Desastre:
Bento Gonçalves, 1 - O menor Victório Lonzetti, operário da fábrica de desfibrar linho, de propriedade da Firma Theodoro Etzberger e Companhia, foi, hoje, vítima de um horrível desastre.

Trabalhava ele em uma das máquinas daquele estabelecimento quando teve o braço direito apanhado por ela, ficando com aquele membro e a mão esmigalhados.

Recolhido a casa de saúde, ali sofreu ele a amputação daqueles membros ${ }^{76}$.

Mulher do povo privada de seu único capital, os braços de seu único filho e de seu marido [...].

[Seu filho de 10 anos sofreu acidente] com polias de uma máquina imprópria para sua idade. Ele foi engolido pela máquina e teve o corpo e o crânio em frangalhos.

[Seu marido veio a morrer] de tuberculose adquirida no serviço junto a caldeira onde exercia a dupla função de foguista e maquinista improvisado, coagido a buscar água para a caldeira, num açude distante, em pleno inverno e sob as rajadas frias do vento norte!

Sem ajuda do marido e do filho, a mulher está abandonada a própria sorte, com fome e desprotegida.
\end{abstract}

\footnotetext{
${ }^{71}$ Conforme denunciava a "União dos Chapeleiros" n'A Democracia, Porto Alegre, 4/8/1907: “Havia (não sabemos se ainda há) no interior da oficina Teichmann um botequim onde eram vendidos aos operários da mesma - e só a eles - cachaça, vinhos e outros líquidos alcoólicos". Conforme também denunciavam articulistas d'A Luta, em 19/7/1908, o álcool (a cachaça) se encontrava disponível, só que de forma gratuita, na "Fábrica Alberto Bins", nos dias em que havia a prática da fundição - inclusive para as crianças.

72 Ver anúncio em A Federação de 2/2/1892 que traz este dado para a "Companhia Manufatura" de Porto Alegre e A Democracia, de Porto Alegre, em 4/6/1905, p. 1,2 para a oficina do periódico A Federação.

${ }^{73}$ A Luta, Porto Alegre 13/9/1906, p. 2.

${ }^{74}$ Conforme se conclui de fragmentos de descrição exaltosa (sic) feita por articulista d'O Diário sobre os novos estabelecimentos (ampliação) da "Fábrica Alberto Bins": "A seção de camas, a mais silenciosa da fábrica por não dispor de máquinas barulhentas e ensurdecedoras como as das outras seções [de cofres, fogões, serralheria, pintura e baldes], caracteriza-se pela falta das chapas brutas, trabalhando apenas os seus operários com delgados tubos, que são cortados, curvados e perfurados para formarem no conjunto as camas higiênicas, tão apreciadas da fábrica Bins." Ver O Diário, Porto Alegre, 29/10/1911, p. 14.

${ }^{75}$ Ver, por exemplo, notícias de sinistros constantes em: Correio do Povo, Porto Alegre: 15/4/1896, p. 1; 2/6/1897, p. 2 ; 26/4/1898, p. 2; 23/3/1917, p. 4; 18/8/1911, p. 8; A Gazetinha, Porto Alegre, 16/9/1897, p. 2 ; $A$ Democracia, Porto Alegre: 11/6/1905, p. 2; 7/4/1907, p. 3; Echo Operário, Rio Grande, 23/1/1898, p. 3; Echo do Povo, Porto Alegre, 24/7/1911, p. 3; O Diário, Porto Alegre: 12/4/1912, p. 5; 29/10/1912, p. 5 e A Federação, Porto Alegre, 10/1/1913, p. 3; 15/2/1913, p. 3.

${ }^{76}$ Correio do Povo, Porto Alegre, 2/3/1917, p. 6.
} 
Por isso a Bigorna conclama aos moradores de Encruzilhada que ajudem e também abre a subscrição com 101 volumes das obras de Vitor Hugo em beneficio desta mulher de nome Júlia ${ }^{77}$.

No estudo de Esmeralda Blanco de Moura, “Mulheres e menores no trabalho industrial: os fatores sexo e idade na dinâmica do capital ${ }^{78}$, que trata dos acidentes de trabalho em São Paulo nos anos de 1890 a 1919, a autora concluiu que estes eram o resultado não somente das precárias condições de trabalho dos operários, como também das condições de vida e da fadiga que os operários sofriam. Segundo ela, os operários, além de sofrer uma jornada de trabalho estafante (com a presença de trabalhos extraordinários e noturnos) e de serem as unidades de produção do período altamente perigosas (com máquinas obsoletas e inseguras) e insalubres (úmidas, sem luz, com pouco ar e com ruídos excessivos), ainda moravam em habitações com pouca ventilação e luminosidade, localizadas em bairros com infraestrutura básica precária e que eram bastante distantes dos locais de trabalho ${ }^{79}$.

Mesmo que não tenha feito para o Rio Grande do Sul uma pesquisa tão minuciosa como a de Blanco Moura a respeito das causas que motivavam os acidentes nos espaços fabris, constatei alguns elementos que indubitavelmente podem ser arrolados como "causas", ainda que não de forma exclusiva, para a ocorrência de acidentes nestes locais e que são bem reveladores das condições de periculosidade existentes nas indústrias do estado. Conforme percebi, alguns acidentes ocorriam pela falta de manutenção das máquinas ${ }^{80}$, ou pelo conserto destas em movimento ${ }^{81}$, por crianças (10 anos) trabalharem com "máquinas impróprias para sua idade" ${ }^{82}$, pela falta de equipamentos de proteção corporal $^{83}$, pela alta periculosidade industrial de algumas unidades de trabalho (com a

\footnotetext{
${ }^{77}$ A Bigorna, "Encruzilhada", 22/9/1917, p. 2.

${ }^{78}$ MOURA, Esmeralda B. Mulheres e menores no trabalho industrial: os fatores sexo e idade na dinâmica do capital. Petrópolis: Vozes, 1982.

79 Idem, Ibidem, p. 78-96.

${ }^{80}$ A Luta, Porto Alegre, 1/7/1907, p. 2.

${ }^{81}$ O Diário, Porto Alegre, 29/10/1912, p. 5.

${ }^{82}$ A Razão, Rio Grande, 1/5/1896, p. 2.; A Bigorna, "Encruzilhada", 22/9/1917, p. 2.

${ }^{83}$ Ver o Correio do Povo, Porto Alegre, 18/8/1911, p. 8. Algumas indústrias, como a metalúrgica de Alberto Bins, já dispunham de alguns desses equipamentos de proteção: "Um operário preservado por uma espécie de escafandro, com uma mangueira guia o jato de areia contra a superfície do cofre (...)". Ver O DIÁRIO, Porto Alegre, 29/10/1911, p. 14.
} 
presença de caldeiras a vapor, que podiam explodir pelo excesso de calor ${ }^{84}$, e também pela 'livre' presença de substâncias voláteis, explosivas e/ou escaldantes: a pólvora, o querosene, o estanho quente etc. $)^{85}$

Nem as crianças escapavam desses acidentes, como se vê na notícia do jornalista $d^{\prime} A$ Luta relatando a saída dos trabalhadores da fundição Bins, onde contou umas vinte crianças:

\begin{abstract}
Conseguimos alcançar um dos que mais retardatário caminhava, puxando duma perna como que ferido.

Era magro, descorado, faces tisnadas, lábios frouxos, olhos encovados, negros e vivos, assentam indagadores sobre nós.

Interrogamo-lo. Chama-se Roberto Lopes, filho de operário que trabalhou na Fábrica de Tecidos e hoje se acha sem trabalho.

Disse-nos ganhar $30 \$ 000$ por mês, ordenado percebido por muitos de seus companheiros, havendo, porém, outros que, em igual trabalho, ganham apenas 800 réis por dia. O horário para eles é o mesmo que para os adultos e são constantemente vigiados por iracundos 'mestres' que não lhes deixam momentos de descanso.

Há dias, contou-nos, muito ingênua e camaradamente o pequeno operário, quando trabalhava em soldagem, caiu-lhe uma porção de metal que estava em ebulição, entre o elástico da velha botina e o pé. O pobre rapaz instintivamente, ao sentir a dor da queimadura, com a mão apertou o cano da botina a ver se conseguia 'apagar a bola de estanho quente', produzindo assim maior queimadura ainda. Oito dias esteve de cama, sendo-lhe descontado do minguado salário e inda não estava bem curado, mas... precisava trabalhar para ganhar aqueles vinténs de que muito servia à sua família.

Estávamos em frente à sua casa, um triste tugúrio da tábua que, com as últimas chuvas se achava rodeado d'água e o operariozinho deu-me a mão, muito e muito fria, em despedida e sumiu-se numa porta que rápida se abriu e se fechou [...] ${ }^{86}$.
\end{abstract}

Um outro fator encontrado, só que bem mais frequente, para a ocorrência de tais acidentes era o fato de o corpo do operário se encontrar perigosamente exposto às novas máquinas motrizes (aquelas que dão movimento ao conjunto dos maquinários), mais encontradas, conforme se pode deduzir do caráter inovador e potente destas novas máquinas, nas fábricas do que nas oficinas.

É pertinente aqui mencionar que nos espaços fabris do período havia diferentes "tipos" de máquinas, desde aquelas que se pode chamar de "arcaicas", presentes mais comumente nas oficinas, até as que se podem denominar de "modernas" ou "novas", presentes nas fábricas.

\footnotetext{
${ }^{84}$ Ver, por exemplo, sinistro anunciado no Echo do Povo, 4/6/1911, p. 1, sobre explosão de caldeira numa fábrica de conservas da região do Salto.

${ }^{85}$ Ver, dentre outros, o Correio do Povo, Porto Alegre em $15 / 04 / 1896$, p. 1 ; 2/6/1897, p. 2; 26/4/1898, p. 2; 2/8/1911, p. 6; 28/10/1913, p. 4; 23/3/1917, p. 4.

${ }^{86}$ A Luta, Porto Alegre, 19/7/1908, p.2.
} 
As primeiras se caracterizavam por serem simples, compostas por poucas peças e por serem movidas por energias de baixa potência: a muscular (humana e animal) e também na zona colonial - pelas naturais (o vento e a água). Este tipo de máquina, devido à própria fonte mais fraca que a animava, não dispunha de uma máquina motriz central complexa, nem de um significativo número de peças de transmissão de energia. Em alguns casos, como informam trabalhos sobre tecnologia e máquinas ${ }^{87}$, encontravam-se dispostas em uma unidade a máquina motriz e a máquina propriamente dita.

Já com relação às máquinas "modernas" ou "novas", o que se tem é o inverso disso. Várias unidades de máquinas sendo postas em movimento por uma complexa e potente máquina motriz central. Daí a razão de as peças de transmissão de energia desta máquina motriz (as engrenagens, correias, volantes etc.) serem mais numerosas e se movimentarem em maior velocidade, necessitando, em razão disso, de um algum tipo de dispositivo de proteção para que não oferecessem perigos ao corpo do operário, o que, conforme se observou dos relatos desses acidentes, bem como da recorrência deles, não ocorria ${ }^{88}$.

Ilustrando um pouco a causa desta periculosidade industrial mencionada, transcrevo abaixo fragmento de notícia de sinistro publicada no Correio do Povo:

Fábrica de massa do Srs. Lopes Duarte \& Machado. Passando [Luiz Facolino - 14 anos -] pelo motor a vapor que faz girar as máquinas da fábrica, e que estava na ocasião em movimento, colocou a mão entre a polia e o volante do mesmo. Felizmente, para ele, a polia não o colheu, apesar de ter ficado machucado ${ }^{89}$.

Em suma, onde havia estas novas máquinas motrizes, havia perigo, o que, como se pode deduzir, também significa que várias foram as unidades fabris no estado que apresentaram tal periculosidade, já que um significativo número de industrialistas dispunha destas novas máquinas em seus estabelecimentos. Nos desastres que ocorriam com este

\footnotetext{
87 JACOMY, Bruno. A era do controle remoto: crônicas da inovação técnica. Rio de Janeiro: Jorge Zahar Ed. 2004, p. 88-89; HENDERSON, William O. A revolução Industrial: 1780-1914. São Paulo: Verbo; Ed. da Universidade de São Paulo, 1969, pp. 12-64.

${ }^{88}$ Confira-se sobre estes acidentes, bem como sobre esta causa que os provocava, as inúmeras notícias de "desastres" constantes em: A Gazetinha, Porto Alegre: 16/9/1897, p. 2; A Democracia, Porto Alegre: 11/6/1905, p. 2; 7/4/1907, p. 3; Echo Operário, Rio Grande, 23/1/1898, p. 3; Echo do Povo, Porto Alegre: 24/7/1911, p. 3; O Diário, Porto Alegre: 12/4/1912, p. 5; 29/10/1912, p. 5; A Federação, Porto Alegre: $10 / 1 / 1913$, p. 3; 15/2/1913, p. 3; e Correio do Povo, Porto Alegre: 30/7/1896, p. 2; 15/9/1897, p. 1; $20 / 12 / 1898$, p. 2 ; $31 / 10 / 1899$, p. 2 ; $26 / 7 / 1899$, p. $1 ; 10 / 3 / 1900$, p. $2 ; 24 / 1 / 1901$, p. $1 ; 26 / 2 / 1901$, p. 2 ; $12 / 5 / 1911$, p. $4 ; 2 / 6 / 1911$, p. $4 ; 23 / 7 / 1912$, p. $4 ; 12 / 11 / 1912$, p. $5 ; 17 / 7 / 1912$, p. $2 ; 19 / 1 / 1915$, p. 4,5 ; $11 / 4 / 1915$, p. 5; 2/3/1917, p. $6 ; 15 / 3 / 1917$, p. 5; 5/12/1917, p. 5; 14/12/1917, p. 2.

${ }^{89}$ Correio do Povo, Porto Alegre, 15/9/1897, p. 1.
} 
tipo de máquina, o esmagamento e até a mutilação de membros do corpo ${ }^{90}$ acabavam sendo, muitas vezes, o menor dos males, uma vez que as peças do sistema de transmissão de energia destas máquinas também dilaceravam os corpos... Exemplifica esta tragédia o seguinte relato de acidente ocorrido na nova fábrica de cervejas Bopp \& Irmãos, noticiado no jornal O Diário de Porto Alegre, em 1912:

Horrível desastre. Um operário esmagado na fábrica de cerveja Bopp Irmãos. Na fábrica de cerveja da firma Bopp Irmãos, estabelecida a rua Cristóvão Colombo n.61, deu-se ontem, ás 7 horas da noite, horrível desastre que confrangeu a todos quantos deles tiveram conhecimento.

Há três para quatro meses trabalhava nesta fábrica como foguista o operário Alzemimo José Ferreira.

Com o seu irmão Theodomiro Ferreira trabalhava na seção de máquinas, revezando-se ambos no serviço.

Como de costume trabalhou Alzemimo, ontem, até as 7 horas da noite, devendo ser rendido ás 10 horas por Theodomiro.

Justamente aquela hora indo ele lubrificar o grande compressor de amoníaco para a fabricação de gelo, descuidou-se, ao que parece, sendo colhido pela correia do grande volante da máquina principal que dá movimento a todas as outras.

Passou-se então uma cena horrorosa, indescritível: a correia, que fez 120 rotações por minuto e é acionada por 80 cavalos de força levou-o consigo enrodilhando-o logo.

Nesse estado fez ele, naturalmente já sem vida, diversas voltas sendo imprensado na cava do volante por onde passou diversas vezes.

Com o corpo já esmigalhado e reduzido a uma massa informe acompanhou a velocidade da correia, até que esta, cedendo a formidável tensão, rebentou, atirando-o contra o teto, 5 metros acima!

Rota a correia de transmissão, que mede meio metro de largura e é também de grande espessura, adaptada ao volante que tem 3 1/2 metros de diâmetro, cessou subitamente o movimento da maquinaria.

A iluminação elétrica da fábrica, produzida por um dínamo próprio, apagou-se.

O ajudante de Alzemimo, Ernesto Fernandes, que punha carvão na fornalha, vendo apagarem-se as luzes gritou a Alzemimo, sem saber de seu trágico fim, perguntando-lhe o que havia.

Não obtendo resposta, dirigiu-se para fora, supondo que tivesse havido algum desarranjo numa outra dependência.

Nessa ocasião trabalhavam no escritório, na frente do edifício, os irmãos Alberto, Carlos e Arthur Bopp, que se viram imediatamente as escuras.

A fim de sindicar o estranho fato, saiu o Sr. Athur Bopp e chegando á casa das máquinas abriu a chave da iluminação elétrica fornecida pela companhia Fiat e que tem de prevenção.

Ao iluminar o recinto depararam seus olhos com uma visão dantesca.

O piso, de cimento, estava juncado de fragmentos de ossos, pedaços de carnes e músculos.

A cor negra das máquinas apresentavam manchas rubras, tintas que estavam de sangue.

${ }^{90}$ Ver: A Gazetinha, Porto Alegre, 11/3/1899, p. 2; Correio do Povo, Porto Alegre, 26/7/1899, p. 1; 31/10/1899, p. $2 ; 24 / 1 / 1901$, p. $1 ; 12 / 5 / 1911$, p. $4 ; 12 / 11 / 1912$, p. $5 ; 11 / 4 / 1915$, p. $5 ; 14 / 12 / 1917$, p. $2 ; 2 / 3 / 1917$, p. 6 ; 5/12/1917, p. 5; 23/3/1917, p. 4; 10/3/1900, p. 2; 5/12/1917, p. 5; A Democracia: 9/7/1905, p. $1 ; 11 / 6 / 1905$, p. 2.; 7/4/1907, p. 3 e Echo Operário, Rio Grande, 23/1/1898, p. 3. 
Na cavidade do volante se encontravam os miolos do infeliz operário.

A parede apresentava uma larga mancha sangrenta, como se contra ela houvessem arremessado postas de carne.

Era muito bem visível no teto a marca dos pés, não uma, mas muitas vezes.

Atrás do compressor de amoníaco para a fabricação do gelo estava o cadáver mutilado de Alzemimo, estirado, de bruços. Era medonho o seu aspecto, das pernas e braços, só haviam os sinais. O tronco nem figuração tinha com o de um ser humano. O cérebro estava partido, faltando uma parte do frontal, por onde se extravasou a massa encefálica, ficando oca a caixa craniana.

Horrorizado o Sr. Arthur Bopp, retirou-se logo comunicando a tristíssima ocorrência a seus dois irmãos e ao 3 ㅇ posto.

Compareceu daquela repartição o inspetor Álvaro Rocha, tendo a assistência mandado o enfermeiro Manoel Rodrigues. Aquele inspetor mandou que o cadáver fosse transportado para o necrotério da chefatura de polícia.

Entrementes comparecia, chamado por Evaristo Fernandes, Theodomiro Ferreira, irmão da vítima.

Por ele se soube que Alzemimo residia, á rua Benjamim Constante, sendo casado há dois anos com D. Idalina Coutinho. Tinha 27 anos de idade e era de cor branca.

Sua morte em tão horríveis circunstâncias impressionou profundamente não só a seus companheiros e chefes, como a numerosa multidão de curiosos que afligiu ao local.

O cadáver será autopsiado, hoje, pelos médicos legistas da polícia.

A fábrica só começou a funcionar de novo ás 10 1 12 horas da noite ${ }^{91}$.

Por fim, ressalto que alguns acidentes estavam acontecendo devido ainda a dois outros fatores. Um deles era resultante de as peças cortantes e perfurantes dos maquinários - aquelas que geralmente se chamam de "perigosas": serras, lâminas, agulhas etc. - não estarem ainda protegidas para o seu "bom uso" pelo trabalhador. Aponto isto considerando não somente os acidentes que ocorreram com essas peças ${ }^{92}$, mas também tendo em vista o fato de as máquinas no século XIX e no início do XX terem sido criadas a partir de uma perspectiva eminentemente utilitária, conforme se vê de análises constantes em obra de John Heskett ${ }^{93}$. Ou seja, tais acidentes estavam ocorrendo como resultado desta preocupação central com a utilidade dos maquinismos (sua função), que não considerava, no caso, qualquer preocupação em proteger o corpo de quem os manuseava.

Já o outro fator seria a coexistência, como mencionei, de oficinas e fábricas, inclusive numa mesma unidade de trabalho, de onde se depreende que se vivia uma realidade tecnológica "94 "multitemporal", pois havia a coexistência de ferramentas de trabalho e

\footnotetext{
${ }^{91}$ O Diário, Porto Alegre, 12/4/1912, p. 5.

${ }^{92}$ Ver, por exemplo, acidentes relatados no Correio do Povo, Porto Alegre, 30/7/1896, p. 2; 2/2/1901, p. 1; e em A Democracia, Porto Alegre, 11/6/1905, p. 2; 9/7/1905, p. 1.

${ }^{93}$ Ver HESKETT, John. Desenho industrial. Rio de Janeiro: José Olympio, 1997, pp. 27-30; 166.

${ }^{94}$ Como aponta Tim Ingold, não há uma definição consensual sobre 'tecnologia' na bibliografia que trata do tema. Porém, em termos amplos, ela pode ser entendida como o conjunto de artefatos, comportamentos e
} 
máquinas arcaicas (movidas à força humana ou animal) e mais modernas (como as movidas a vapor e, posteriormente, a eletricidade $)^{95}$ e uma relativa não sintonia entre esta última forma de tecnologia emergente e boa parte da qualificação operária existente. Esclarecendo melhor este último ponto, não se pode esquecer que, se por um lado ocorria um processo de destituição do "saber-fazer" do artesão, isso não significava sua supressão imediata - até porque muitas fábricas abrigavam as oficinas ou a elas se conjugavam. Além disso, havia o fato de que muitos homens e mulheres estavam entrando pela primeira vez em uma fábrica $^{96}$, e de que mesmo aqueles que já haviam dominado algumas técnicas de manuseio de um maquinário mais simples, teriam de incorporar novas técnicas e ritmos, quando da lida com máquinas mais novas.

Tendo em vista tal quadro, não é difícil supor que o resultado desta falta de sintonia fosse $o$ de alguns acidentes e mutilações, já que as novas técnicas ${ }^{97}$ (onde se incluem velocidade e ritmo) exigidas para o manuseio das máquinas (principalmente as mais novas) não haviam sido ainda totalmente incorporadas pelos corpos em questão. Não seria difícil pensar, tendo em vista o exposto, que o acidente relatado abaixo tivesse como causa o que foi mencionado.

\begin{abstract}
Na quarta-feira última foi vítima de um desastre, na fábrica de calçados Progresso Industrial, de que é empregado, o laborioso operário Adão Michalski. O lamentável sucesso ocorreu na ocasião em que aquele profissional cortava sola em uma nova máquina.

Apesar de reconhecidamente competente no trabalho em que se achava, Adão sofreu a infelicidade de, por descuido ou por qualquer circunstância fortuita, ter o dedo polegar da mão esquerda colhido pela faca da máquina, que dividiu-o a meio quase que em toda a extensão. Adão foi medicado na Beneficência Portuguesa. Lamentando sinceramente o desastre, fazemos votos pelo restabelecimento do inditoso obreiro, que é um dedicado ao movimento reivindicador dos direitos do operariado $^{98}$.
\end{abstract}

conhecimentos empregados na transformação e utilização do mundo material. Ver INGOLD, Tim. "Tools, minds and machines: un excursion in the philosophy of technology". Techniques e culture, n. 12, 1988, pp. 151-176.

${ }^{95}$ Vários anúncios de venda de máquinas por lojas e donos de fábricas e oficinas ilustram bem isto. Assim, o anúncio de venda de máquinas "para fabricação de massas alimentícias [...] movidas à eletricidade, a cavalo e a vapor." E de que há "pessoa habilitada para montagem das máquinas e para ensinar a fabricar pelo sistema mais moderno." Ver: Correio do Povo, Porto Alegre, 27/11/1913, p. 3. Outro exemplo é o de máquina para fabricação de gasosa, movida a mão ou a força motriz . Ver: Correio do Povo, Porto Alegre, 7/10/1913, p. 13. Ver ainda o anúncio de autoria de proprietário de fábricas constante n' O Diário, Porto Alegre, 22/7/1913, p. 7.

${ }^{96}$ É interessante, a respeito disso, o que informa no ano de 1912 a fábrica de calçados Godiar-Well, da firma Becker e Irmão, localizada em Novo Hamburgo: "Realizaram aprendizagem cerca de 100 operários que antes nunca haviam trabalhado em máquinas." Ver O Diário, Porto Alegre, 8/8/1912, p. 2.

${ }^{97}$ Conforme LEMONNIER, P. The study of Material Culture Today: Toward an Anthropology of Technical Systems. Journal of Anthropological Archaeology, n. 5, 1986, p. 4-6.

${ }_{98}$ A Democracia, Porto Alegre, 24/03/1907, p. 3. (Grifo meu). 
É pertinente ainda observar, em se tratando de acidentes, que a culpa pela ocorrência deles era, via de regra, atribuída aos operários pelos patrões, quando não eram ainda minimizados em sua importância, mesmo que resultassem em algum prejuízo físico ao operário $^{99}$. Um exemplo bastante convincente, e que revela o quanto o corpo do trabalhador era concebido pelo capital como um mero instrumento de produção que poderia ser "gasto" no trabalho, é o caso do acidente ocorrido na Fundição Berta (futura fábrica Alberto Bins) com o operário sueco Johann Lind, que veio a ter um dedo amputado em consequência disto ${ }^{100}$. Após inúmeras justificativas do industrialista Emmerich Berta em página do Correio do Povo, sobre os motivos do acidente ocorrido em sua fábrica, todas inculpando o operário, aquele ainda foi capaz de afirmar que a "triste ocorrência" não teve "graves conseqüências" para este trabalhador! ${ }^{101}$ Um outro exemplo que pode ainda revelar este descaso com o corpo do operário é o acidente ocorrido na Cervejaria Bopp \& Irmãos, transcrito anteriormente. Como consta na descrição deste desastre feita por O Diário, a fábrica voltou a funcionar, "à (sic) todo vapor", após somente 3 horas e $1 / 2$ do sinistro que vitimou o operário, e que, segundo o jornal, foi um período de tempo extremamente longo...

Tratando, por fim, da situação salarial do operariado no estado, observo que ela não era, ao que tudo indica, também muito salutar.

Os dados trazidos pela imprensa operária e comercial do período, bem como pelos próprios documentos oficiais, revelam que muitos dos valores que vinham se mostrando como recorrentes para os salários operários masculinos - e que talvez se referissem às próprias médias destes salários no estado à época - eram "curtos", quando não insuficientes, para dar conta das necessidades mínimas de uma família operária, caso se considere que somente o pai trabalhasse, como era desejável em razão da moralidade do período.

Conforme constatei a partir desta documentação, entre os anos de 1890 a 1910 muitos destes salários encontravam-se situados entre os valores de $2 \$ 000$ a $5 \$ 000$ réis

\footnotetext{
${ }^{99}$ Ver, entre outros, notas no Correio do Povo, Porto Alegre, 11/3/1900, p. 2 e em A Federação, Porto Alegre, 25/11/1912. Em períodos posteriores, já com a existência da "Lei de Acidentes de Trabalho", esta "culpabilização" do operário em face dos acidentes de trabalho também permanece. Ver denúncia em jornal operário que evidencia isso: O Syndicalista, Porto Alegre, 15/11/1927, p. 2 e 3.

${ }^{100}$ Correio do Povo, Porto Alegre, 10/3/1900, p. 2

${ }^{101}$ Correio do Povo, Porto Alegre, 11/3/1900, p. 2
} 
diários $^{102}$. Na Cervejaria Ritter \& Filho, por exemplo, eles seriam de $2 \$ 000,2 \$ 500$ e $3 \$ 000$ réis/dia ${ }^{103}$; já um operário com ofício em Pelotas estaria recebendo, em 1893, algo em torno de $3 \$ 500$ réis $^{104}$; na Cia. Fiação e Tecidos de Porto Alegre, para citar mais um exemplo, este salário teria alcançado o teto de $4 \$ 000$ réis em $1910^{105}$. Para o período que segue de 1910 a 1915 não obtive maiores informações a respeito destes salários, mas em 1916 vê-se que alguns proventos masculinos subiram em Porto Alegre, chegando ao teto médio de $6 \$ 000$ réis/dia ${ }^{106}$.

Com relação ao salário das mulheres e crianças não pude estabelecer maiores conclusões, mas obtive índices que dão valores de $1 \$ 500,2 \$ 500(1906-1911)$ e de $4 \$ 000$ réis (1916) para aquelas ${ }^{107}$; e de 1000 e $1 \$ 300$ (1906-1909) para as crianças $^{108}$.

Esta afirmação de que os proventos masculinos vinham se mostrando "curtos" para a sobrevivência operária, caso somente o homem trabalhasse, toma por base um exercício por mim realizado que, acredito, torna visíveis valores que poderiam ser considerados como mínimos para a sobrevivência desta classe na primeira década de 1900.

Este exercício, similar ao que fazia a imprensa operária da época para demonstrar a insuficiência do salário, compara a receita e a despesa de uma família proletária. Naqueles balanços se consideravam os gastos com o aluguel, água, serviços sanitários e alimentação, itens todos estes que compõem o exercício que realizo. Noto também que a quantidade e os itens alimentícios que estão presentes no balancete, bem como o próprio número de

\footnotetext{
${ }^{102}$ A este respeito, ver dados constantes em $A$ Luta de 6/1/1908, p. 2 (padeiros estariam recebendo em torno de $3 \$ 000$ réis/dia); no Correio do Povo, $11 / 4 / 1900$, p. 5 (oferta de vaga para sapateiro a $3 \$ 5000$ e $4 \$ 000$ réis/dia); em A Democracia, Porto Alegre, 13/8/1905, p. 3 (a média do salário de um tecelão da Cia. Fiação e Tecidos seria, em 1905 , de $90 \$ 000$ mensais - 3\$400 réis ao dia) e de 21/5/1905 (consta carta dirigida ao Intendente de Porto Alegre exigindo que os salários dos trabalhadores da construção da Caixa d'água do Moinho de Vento sejam de $2 \$ 000,3 \$ 000,3 \$ 5000$, e não de $2 \$ 000$ e $3 \$ 000$ réis/dia). Ver ainda a respeito, informes de que a média do salário de um operário no sul do Brasil era de $3 \$ 500,4 \$ 000$ e $5 \$ 000$ réis ao dia: $A$ Luta, Porto Alegre: 17/1/1907, p. 4; A Democracia, Porto Alegre, 6/1/1907, p. 3; O Proletário, Porto Alegre, 9/8/1896, p. 3 e Echo Operário, Rio Grande, 17/7/1898, p. 1-2.

${ }^{103}$ A Luta, Porto Alegre, 16/1/1909, p. 4.

${ }^{104}$ Democracia Social, Pelotas, 9/7/1893, p. 2

${ }^{105}$ A Luta, Porto Alegre, 1/5/1910, p. 2.

${ }^{106}$ Ver Relatório apresentado ao Ex. Sr. Dr. Protásio Alves / Secretaria do estado dos Negócios do Interior e Exterior pelo Diretor Interino Nathaniel Cunha (1916). S.n.t.

${ }^{107}$ A Luta, Porto Alegre: 1/5/1910, p. 2 (Cia. Fiação e Tecidos, salários de 500 a 1\$000; alguns poucos iam até $3 \$ 000) ; 20 / 1 / 1911$, p. 1 (informe "geral" de que em fábricas de tecidos, meias, gravatas e roupas se recebia de 500 a $2 \$ 000$ réis). Ver ainda: Relatório apresentado ao Ex. Sr. Dr. Protásio... Op. cit.

${ }^{108}$ A Luta, Porto Alegre: 15/12/1906, p. 4; 19/7/1908, p. 2 (Fundição Bins e Cia. Fiação e Tecidos. Proventos de $500,800,1 \$ 000$ e $1 \$ 300$ réis).
} 
membros da família operária foram baseados numa média dos dados apresentados pela imprensa operária ${ }^{109}$, a fim de guardar proximidade com os hábitos culturais desta classe. Por outro lado, os valores desses itens e outros constantes no meu balancete foram obtidos a partir de uma média dos valores presentes em informativos gerais e em anúncios de estabelecimentos comerciais publicados na primeira década de 1900 na imprensa operária e no Correio do Povo ${ }^{110}$. A escolha dessa década deve-se ao fato de ser um período em que a economia brasileira estava um pouco mais estável e os preços estariam, então, oscilando menos.

Inicio este balancete comentando que a família operária aqui pensada era composta por cinco membros - casal e três filhos - e que seus gastos seriam os seguintes, excetuando vestuário, médicos e remédios.

\footnotetext{
${ }^{109}$ Alfaiate, Porto Alegre, 12/10/1907, p. 2. A Democracia, Porto Alegre, 6/1/1907, p. 2-3; A Luta, Porto Alegre, 6/1/1908, p. 2; Echo Operário, Rio Grande, 3/9/1899, p. 2; Democracia Social, Pelotas, 9/7/1893, p. 2.

${ }^{110}$ Para os preços dos alimentos considerei o anúncio do "Armazém Pereira" publicado no jornal $A$ Democracia, Porto Alegre, 15/10/1905, p. 3-4 e os informativos no Correio do Povo sobre os preços correntes no Mercado Público da capital, Correio do Povo, 3/8/1900, p. 2; 4/8/1900, p. 2 e 3/5/1911, p. 7. Já para o valor dos aluguéis de moradia os anúncios de casas pequenas (de 3, 4 e 5 peças) para alugar, via de regra em localidades simples de Porto Alegre (em zonas "modestas" - como a rua dos Venezianos - e arrabaldes), publicados no Correio do Povo, em 13/5/1900, p. 2; 20/5/1900, p. 3; 25/5/1900, p. 2 e 5/5/1911, p. 7; 6/5/1911, p. 4, bem como outros dados constantes sobre estes valores na imprensa operária do estado: O Alfaiate, Porto Alegre, 12/10/1907, p. 2. A Democracia, Porto Alegre, 6/1/1907, p. 2-3; A Luta, Porto Alegre, 6/1/1908, p .2; Echo do Povo, Porto Alegre, 11/10/1909, p. 3; Echo Operário, Rio Grande, 3/9/1899, p. 2; Democracia Social, Pelotas, 9/7/1893, p. 2. Já para os valores do custo de água e serviços sanitários, usei os índices médios trazidos pela imprensa operária do estado acima arrolada.
} 


\begin{tabular}{|c|c|}
\hline $\begin{array}{l}\text { Aluguel: } \mathbf{3 0} \$ \mathbf{0 0 0} \\
\text { Água: } 4 \$ 500\end{array}$ & $\begin{array}{l}\text { Açúcar (2 kg a } 350 \text { réis o } \mathrm{kg} \text { ): } 700 \\
\text { Feijão (10 kg a } 160 \text { réis o kg): } 1 \$ 600 \\
\text { Arroz (10 kg a } 300 \text { réis. o kg): } 3 \$ 000\end{array}$ \\
\hline $\begin{array}{l}\text { Serviços sanitários (aluguel de “cuba"): } 1 \$ 200 \\
\text { Armazém: } 48 \$ 945 \text { (abaixo discriminado) }\end{array}$ & $\begin{array}{l}\text { Farinha ( } 2 \mathrm{~kg} \text {. a } 300 \text { réis o kg): } 700 \\
\text { Batata ( } 5 \mathrm{~kg} \text { a } 60 \text { réis o } \mathrm{kg} \text { ): } 300 \\
\text { Hortalicas variadas: } 720 \text { réis }\end{array}$ \\
\hline 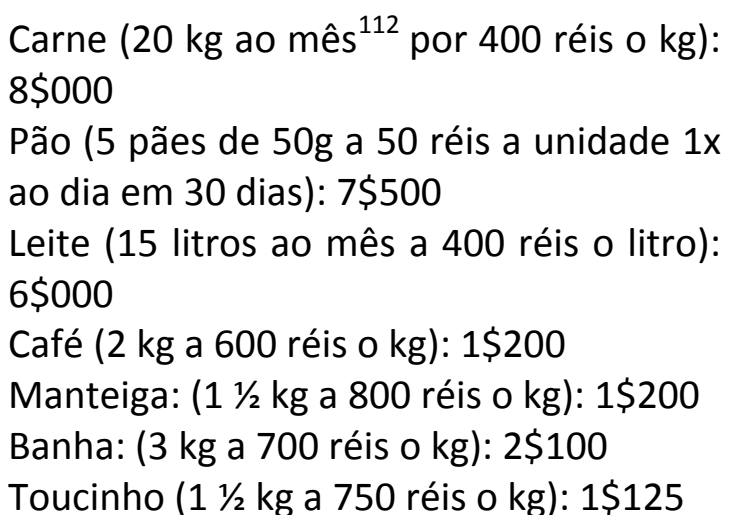 & $\begin{array}{l}\text { Massa para sopa: ( } 1 \mathrm{~kg} \text { a } 100 \text { réis):100 } \\
\text { réis } \\
\text { Sabão ( } 4 \mathrm{~kg} \text { a } 300 \text { réis o } \mathrm{kg} \text { ): } 1 \$ 200 \\
\text { Velas ( } 2 \text { dúzias e } 1 / 2 \text { a } 560 \text { réis/dúzia): } \\
1 \$ 400 \\
\text { Lenha ( } 5 \text { achas } / \text { dia a } 80 \text { réis a acha): } \\
12 \$ 000 \\
\text { Fósforo ( } 1 \text { caixa): } 100 \text { réis } \\
\text { Total: } \mathbf{8 4} \$ \mathbf{6 4 5} \text { réis mensais }\end{array}$ \\
\hline
\end{tabular}

Gostaria de observar, antes de iniciar propriamente a análise, que o operário no RS, pelo que se vê destes itens, tinha uma alimentação baseada sobretudo na carne e em seus derivados, fato perfeitamente compreensível pela grande expansão, no estado, da pecuária. De todos estes "tipos" de alimentos, era provavelmente a carne - pelo que se observa da quantidade prevista no orçamento acima - o elemento central da dieta do operário no estado $^{113}$.

Como se viu anteriormente, o salário de muitos operários oscilava de $2 \$ 000$ a $5 \$ 000$ réis diários no período de 1890 a 1910. Considerando que o mês tem 26 dias de trabalho (já que 4 são domingos), estes operários obtêm, então, índices que variavam de 52\$00 a $130 \$ 00$ réis mensais. Ou seja, somente aqueles trabalhadores que estariam recebendo

\footnotetext{
${ }^{111}$ Valor obtido a partir de uma média entre valores que oscilavam de $20 \$ 000$ a $40 \$ 000$, concentrando-se mais na casa dos $30 \$ 000$

${ }^{112}$ Como se vê, comia-se - ou se desejava comer - bastante carne nesses anos. Menciono, todavia, que em meu cálculo fiz uma "média para baixo" - a fim de evitar exageros -, pois há informes que mencionam que uma família de cinco pessoas deveria comer $1 \frac{1 / 2}{\mathrm{~kg}}$ de carne, quando não $2 \mathrm{~kg}$, por dia, ou seja, de 45 a 60 quilos ao mês!!! Conferir, a respeito disso: Democracia Social, Pelotas, 9/7/1893, p. 2 e A Democracia, Porto Alegre, $6 / 1 / 1907$, p. 3. No entanto, é pertinente observar que a carne não era cara (na média, de 400 a 500 réis o kg) se comparada a outros produtos do período (como a lenha, o café e o arroz).

${ }^{113}$ Edward P. Thompson relata que na Europa, após a Revolução Industrial, a dieta dos populares - aí incluídos os operários - se constituía de cereais, carne, batata, cerveja, açúcar e chá, ocupando a batata o lugar central nesta alimentação. Ver THOMPSON, E. P. A formação da classe operária inglesa. A maldição de Adão. São Paulo: 1988, pp. 179-184.
} 
acima de $3 \$ 255$ réis/dia poderiam fechar este balanço no positivo ( $3 \$ 255 \times 6$ dias semanais de trabalho x 4 semanas ao mês: $84 \$ 645)$, dando conta, então, da alimentação e da moradia, mas não necessariamente viriam a cumprir seu papel de provedor e manteriam, assim, a mulher e filhos no lar, pois faltariam ainda os gastos com vestuário e com médicos e remédios.

Já os operários com proventos de $4 \$ 000$ e $5 \$ 000$ réis/dia (104\$000 e $130 \$ 000$ réis ao mês), teriam um saldo positivo de $19 \$ 355$ e $45 \$ 355$ réis, respectivamente; ou seja, poderiam dar conta dos outros itens mencionados, mas não necessariamente manter a mulher e os filhos em casa, principalmente em situações extraordinárias, como de doença em família.

É pertinente aqui mencionar, até para se entender melhor esta última afirmativa, que os gastos com o vestuário no período - item que não vi constar em valores em nenhum balanço feito na imprensa operária - não eram baixos. Uma calça tida como barata (em saldos/“baratilhos") custava de $12 \$ 000$ a $28 \$ 000$ réis; já uma fatiota, de $15 \$ 000$ a $25 \$ 000$ réis; cortes de tecido baratos (como chita e brim), de 800 a $1 \$ 500$ réis o metro ${ }^{114}$. Para mencionar aqui já um exemplo na área da saúde, um tratamento dentário tido como simples (como uma obturação com massa) ia de $2 \$ 000$ a $4 \$ 000$ réis $^{115}$.

Ou seja, como se vê deste exercício, que, em todo o caso, é apenas hipotético, não eram poucas as famílias operárias que achavam em situação financeira difícil e, consequentemente, viam-se obrigadas a empregar outros de seus membros ${ }^{116}$.

Cabe ainda observar que até os operários solteiros tinham certas dificuldades financeiras para se manter. As pensões, locais em que muitos dos operários solteiros residiam, não eram baratas. Os valores oscilavam, em 1900, entre $50 \$ 000$ e $60 \$ 000$ réis mensais, com duas refeições ao dia, e entre $40 \$ 000$ e $50 \$ 000$, se apenas com uma refeição ${ }^{117}$.

\footnotetext{
${ }^{114}$ A Democracia, Porto Alegre, 11/6/1905, p. 3-4; Correio do Povo, Porto Alegre: 4/4/1909, p. 3; 14/9/1900, p. $2 ; 7 / 6 / 1900$, p. $3 ; 27 / 3 / 1900$, p. 3.

${ }^{115}$ Correio do Povo, Porto Alegre, 22/4/1911, p. 5.

${ }^{116}$ Este fato, conforme demonstram dados presentes na coleção "Nosso Século", também ocorria na Capital Federal, no período aqui em estudo. Nosso Século (1900-1910): A memória fotográfica do Brasil no século XX. São Paulo: Abril, s/d., pp. 24-25.

${ }^{117}$ Ver anúncio no Correio do Povo em 13/6/1900, p. 4, sobre pensão no centro de Porto Alegre, que custava entre $40 \$ 000$ e $60 \$ 000$ (com 1 ou 2 refeições ao dia, respectivamente), bem como outros anúncios e dados sobre pensões, no Correio do Povo de 11/3/1900, p. 1; 14/7/1900, p. 4; 25/7/1900, p. 3 e 13/9/1900, p. 4.
} 
Claro está que deveria haver operários, no estado, que recebiam um salário bem maior, certamente os mais especializados, e que então viveriam melhor. No entanto, conforme se pode deduzir do quadro que aqui tracei, isto era, provavelmente, cada vez menos frequente, pois paulatinamente diminuía o número de artesãos, enquanto crescia o número de operários manuais em face de um restrito número de operários especializados.

Aponto ainda como agravante deste quadro de déficit salarial uma série de crises que a economia brasileira enfrentou, especialmente quando da conjuntura 1914 - 1918, em decorrência dos efeitos da Guerra, crise de emprego, desabastecimento, aumento de preços e carestia ${ }^{118}$. Nesta perspectiva, é importante mencionar que a questão do aumento do salário foi uma pauta constante nas reivindicações operárias e, conforme demonstra a historiografia, o primeiro motivo que levava o operário no estado a fazer greve $\mathrm{e}^{119}$.

A título de conclusão da exposição aqui feita, observo que o operário no estado, no período em estudo, tinha uma realidade fabril não homogênea, no que diz respeito as suas condições de trabalho (higiene e segurança) e salários. Contudo, como penso ter demonstrado, o acento, no caso, não foi na excelência destas condições e proventos, muito pelo contrário. Além disso, também busquei evidenciar que o Capital auxiliou a forjar certos corpos entre os operários, corpos estes tanto marcados pela sua condição de gênero no espaço fabril, como pelas próprias cicatrizes deste trabalho: com amputações, cortes, doença e cansaço.

Recebido em 20/12/2009

Aprovado para publicação em 12/05/2010

\footnotetext{
${ }^{118}$ A esse respeito, especificamente no que toca às suas repercussões para o Rio Grande do Sul, ver LONER, B, op.cit., p. 327-334 e PESAVENTO, S. Os pobres da cidade. Vida e trabalho. 1880-1920. Porto. Alegre: Editora da UFRGS, 1994, pp. 46-53.

${ }^{119}$ PETERSEN, S. “As greves no Rio Grande do Sul na República Velha”. In: DACANAL, J. I. e GONZAGA, S. (org.). RS: economia e política. Porto Alegre: Mercado Aberto, 1993, p. 321. Ver também LONER, B, op.cit., p. 463-466.
} 